\title{
THE EFFECT OF SILICON FOLIAR AND ROOT APPLICATION ON GROWTH, PHYSIOLOGY, AND ANTIOXIDANT ENZYME ACTIVITY OF WHEAT PLANTS UNDER CADMIUM TOXICITY
}

\author{
UR RAHMAN, SH. ${ }^{1,2}-$ QI, X. ${ }^{1,2^{*}}-$ ZHANG, Z. ${ }^{3}-$ ASHRAF, M. N. ${ }^{4}-$ DU, Z. $.^{1,2}-$ ZHONG, Y. L. ${ }^{1,2}-$ \\ MEHMOOD, F. $^{5}-$ UR RAHMAN, $^{6}{ }^{6}-$ SHEHZAD, ${ }^{7}$
}

${ }^{I}$ Farmland Irrigation Research Institute, Chinese Academy of Agricultural Sciences, Xinxiang 453003, China

${ }^{2}$ Key Laboratory of High-efficient and Safe Utilization of Agriculture Water Resources of CAAS, Xinxiang 453003, China

${ }^{3}$ The James Hutton Institute, Craigiebuckler, Aberdeen AB15 8QH, UK

${ }^{4}$ National Engineering Laboratory for Improving Quality of Arable Land, Institute of Agricultural Resources and Regional Planning, Chinese Academy of Agricultural Sciences, 100081 Beijing, China

${ }^{5}$ Farmland Irrigation Research Institute of the Chinese Academy of Agriculture Sciences/Key Laboratory of Crop Water Use and Regulation, Ministry of Agriculture and Rural Affairs, Xinxiang, Henan 453003, China

${ }^{6}$ Department of Soil and Environmental Science, Arid Agriculture University, Rawalpindi, Pakistan

${ }^{7}$ Institute of Cotton Research, Chinese Academy of Agricultural Sciences, Anyang, China

*Corresponding author

e-mail: qxb6301@sina.cn; phone: +86-373-339-3277

(Received $7^{\text {th }}$ Oct 2019; accepted $4^{\text {th }}$ Dec 2019)

\begin{abstract}
Silicon ( $\mathrm{Si}$ ) application can boost plant growth and physiology under heavy metal toxicity. The article aimed to investigate how the foliar and root application of silicon ( $\mathrm{Si}$ ) affects the uptake, translocation, and concentration of cadmium (Cd) for winter wheat (Triticum aestivum L.), and in turn the plant's growth, physiology, and antioxidant enzyme activity, using a complete randomized block design (CRBD)? For this purpose, we used twelve treatments consisting of two levels of Si (0 and $\left.3 \mathrm{mM} \mathrm{Na} \mathrm{SiO}_{3}\right)$ against four levels of $\mathrm{Cd}\left(0,50,100\right.$, and $\left.200 \mu \mathrm{M} \mathrm{CdCl}_{2}\right)$ with three replications. Results showed that all levels of $\mathrm{Cd}$ significantly enhanced membrane permeability measured as malonyldialdehyde (MDA) content, osmotic stress measured as hydrogen peroxide $\left(\mathrm{H}_{2} \mathrm{O}_{2}\right)$ content, and triggered the enzymatic and non-enzymatic antioxidant system, resulting in a severe reduction in the growth of wheat seedlings. Besides, $\mathrm{Si}$ application either as root (SiR3) or foliar spray ( $\mathrm{SiF} 3)$ remarkably encountered $\mathrm{Cd}$ toxicity by further improving antioxidative enzymes activities, and by hindering $\mathrm{Cd}$ uptake, but more significant results were recorded for SiR3. Therefore, it might be established that Si root supplementation inhibited Cd translocation from root to shoot more effectively than foliar application, thereby lowering the potential health risk of $\mathrm{Cd}$ pollution.
\end{abstract}

Keywords: enzymatic and non-enzymatic antioxidants, membrane permeability, osmoprotectants, photosynthetic pigments 


\section{Introduction}

Wheat (Triticum aestivum L.) is the ultimate extensively grown cereal crop which fulfills $20 \%$ of the required daily protein for 4.5 billion people in the world (Flister and Galushko, 2016). It is the second most significant food crop in the developing world after rice. The wheat crop has the ability to adapt to various environmental circumstances but, considerable grain yield loss has been reported under heavy metals contamination, predominantly cadmium (Cd) contaminated soils (Rady et al., 2015). Most of the crop production area is under heavy metal stress caused by industrialization, anthropogenic activities, and other agricultural practices, which is currently becoming a worldwide serious threat (Zabin et al., 2015).

Among heavy metals, $\mathrm{Cd}$ is a highly lethal element because of its relative mobility, high water solubility, and phytotoxicity (Ali et al., 2011; Wuana and Okieimen, 2011). Due to its dynamic fates, $\mathrm{Cd}$ in an ionic form enters into plants through root and being shifted to shoot xylem and phloem through various active transporters and passive transporters (Dong et al., 2019; Takahashi et al., 2012). Higher uptake of Cd reduces photosynthesis by hindering root Fe (III) reductase, affects the activity of the enzyme involved in $\mathrm{CO}_{2}$ fixation, affects mineral absorption causing a nutritional imbalance (such as $\mathrm{N}$ and $\mathrm{K}^{+}$) and results in stomatal closure (Azevedo et al., 2012). It has been reported that in the intensified oxidative processes occur in cells of Cd-stressed plants which caused the formation of massive amount of reactive oxygen species (ROS) (Balakhnina et al., 2015; Gratão et al., 2005) which caused remarkable reduction of anti-oxidative enzymes activities in plants (Song et al., 2009). Additionally, Cd accumulates in the human body via the food chain, causing kidney, bone, and pulmonary damage (Ali et al., 2014; Fu and Wei, 2013; Li et al., 2014). Thus, developing positive approaches to minimize the potential health risk of heavy metal impurity in food chains is urgent for protecting edible parts of crops being polluted by heavy metals.

To alleviate heavy metals toxicity in plants, various means like soil phytoremediation and soil remediation engineering has been practiced (Rascio and Navari-Izzo, 2011). Although in most cases, these means did not work more effectively, as an alternative and/or accompanied by these means, silicon ( $\mathrm{Si}$ ) as soil or foliar application could be a more effective approach to diminish heavy metals accumulation in plants.

Silicon (Si), as a beneficial element, shows a crucial part in the growth and enlargement of various crops (Keeping, 2017; Zhao et al., 2017). Currently, Si has been conceived by Shi et al. (2014) as a compulsory element for numerous higher plants. However, $\mathrm{Si}$ is being proved as useful for plants, and it has the ability to alleviate biotic and abiotic stresses (Dong et al., 2019; Yu et al., 2016; Zhao et al., 2017). Si is the only element that can intake, translocate, and accumulate in considerable quantities in plants without any adverse effects (Ma et al., 2001a). Moreover, Si has been declared as a noncorrosive element (Wang et al., 2016). Consequently, Si, as being high-quality fertilizer may be used for eco-friendly agricultural enhancement.

It has been established in previous findings that $\mathrm{Si}$ can improve plant growth by mitigating the adverse influences of heavy metal toxicity (Dong et al., 2019). Numerous scientists have reported that $\mathrm{Si}$ treatments detoxify $\mathrm{Cd}$-induced stress in various plants, particularly in graminaceous crops, which are deliberated as Si accumulators (Farooq et al., 2013; Howladar et al., 2018; Keeping, 2017; Zhao et al., 2017). Concerning abiotic stresses, Si counters various stresses, including drought, salinity, and heavy metals toxicity included $\mathrm{Cd}$ toxicity in growth medium (Alzahrani et al., 2018). Si, in the form 
of silicates, converts the exchangeable and the soluble fractions of metals into stable chemicals in soil. Such a decline in metal bioavailability is documented to redox reactions, humification, and precipitation (Vieira da Cunha et al., 2008). Besides, Silicates in soil encourages the polymerization of silicate composts and forms heavymetals complexes (Sommer et al., 2006). However, evidence suggesting that Si addition improves photosynthetic activity modifies nutrient imbalance, minimizes mineral toxicity, and enhances abiotic tolerance (Ma et al., 2001a). Si maintains photosynthetic activity in $\mathrm{Cd}$-stressed plants, reducing $\mathrm{Cd}$ uptake from nutrient solution to plant roots and restricts its translocation from root to shoots, which might be the possible mechanism of Cd detoxification (Kabir et al., 2016a).

Reactive oxygen species (ROS) produced in plants by Cd stress, causing a severe distraction of several metabolic processes in plants (Kim et al., 2017). Different responses have been reported against various environmental stresses within the crop, plant species, and/or cultivars according to their antioxidant defense system (Wael et al., 2015). Optimum ingredients of antioxidants in plants either stimulated and/or constitutive induce more tolerance in plants to oxidative burst (Kusvuran et al., 2016). It has been described by Kim et al. (2017) that Si increased plant tolerance to oxidative damage by regulating a substantial amount of different ROS in heavy metal stressedplants. These findings can be justified based on Si amounts in plants, which involves improving activities of antioxidative enzymes; particularly those antioxidants which participated in the transformation of $\mathrm{H}_{2} \mathrm{O}_{2}$ in $\mathrm{H}_{2} \mathrm{O}$, and/or minimizing MDA activity to scavenge negative effects of ROS.

It has been widely studied the protective role of foliar as well as soil application of Si to alleviate the heavy metal toxicity in wheat crops. However, to our best knowledge, this is the first kind of study used Si foliar and root application method in wheat crop to evaluate the most effective $\mathrm{Si}$ application method to raise the capability of wheat to tolerate Cd toxicity.

Consequently, the primary aim of the present study was to find the constructive impact of $\mathrm{Si}$ in two $\mathrm{Si}$ application approaches and to identify the optimum way of $\mathrm{Si}$ supplementation for plant physiological traits, chlorophyll contents, anti-oxidative enzymes activities, proline, $\mathrm{H}_{2} \mathrm{O}_{2}$, and MDA content in Cd-stressed wheat plants grown hydroponically.

\section{Materials and methods}

\section{Experimental layout}

The experiment was conducted at the experimental site of the Farmland Irrigation Research Institute, Chinese Academy of Agricultural Sciences in Xinxiang City, China. Healthy seeds of winter wheat genotype Xin Mai 23 were immersed overnight in deionized water and sown in pasteurized quartz sand trays with the sand layer of 4 inches in width. The sand dishes were placed in a growing chamber of $16 \mathrm{~h} \mathrm{light} / 8 \mathrm{~h}$ dark with a light intensity of $375 \mu$ mole $\mathrm{m}^{-2} \mathrm{~S}^{-1}$. The temperature of the growth chamber was set at $28{ }^{\circ} \mathrm{C}$ to $30{ }^{\circ} \mathrm{C}$ with a relative humidity of $85 \%$. After two weeks of sowing, the five uniform seedlings were enfolded with foam at a root-shoot joint and relocated in each hole (15 in. $\times 17$ in. in size) of plastic sheets fluctuating on $10 \mathrm{~L}$ capacity plastic basins. These basins occupied with $8 \mathrm{~L}$ modified Hoagland's solution (see Appendix heading 1). The $\mathrm{pH}$ was adjusted to 6.5 throughout the experiment by using acid $(\mathrm{HCl})$ and base $(\mathrm{NaOH})$. The air pumps were applied to the aerated nutrient solution. During 
the whole experiment, the nutrient solution was renewed after three days of intervals. After 65 days of transplantation $\mathrm{Cd}$ in the form of cadmium chloride $\left(\mathrm{CdCl}_{2}\right)$ and $3 \mathrm{mM}$ per litter $\mathrm{Si}$ in the form of silicates nanoparticles (made by sodium silicate) (see Appendix heading 2) were added to nutrient solutions for 15 days to form twelve treatments with three replications as shown in Table 1. Si was applied by two different methods; 1) $\mathrm{Si}$ root-application (SiR3), 2) $\mathrm{Si}$ foliar-application (SiF3). In $\mathrm{Si}$ root application, $3 \mathrm{mM} \mathrm{Si}$ as silica gel was applied per liter of nutrient solution after every three days during 15 days of treatments. Alternatively, in Si foliar-application, Si with an amount of $3 \mathrm{mmol} / \mathrm{L}$ in the form of silica gel was sprayed five times during 15 days of treatment in 100 days experiment.

Table 1. Experimental treatments

\begin{tabular}{c|c|c|c}
\hline Treatments & Cd $(\boldsymbol{\mu M})$ & SiR $(\mathbf{m M})$ & SiF $(\mathbf{m M})$ \\
\hline Ck & 0 & 0 & 0 \\
T2 & 0 & 3 & 0 \\
T3 & 0 & 0 & 3 \\
T4 & 50 & 0 & 0 \\
T5 & 50 & 3 & 0 \\
T6 & 50 & 0 & 3 \\
T7 & 100 & 3 & 0 \\
T8 & 0 & 0 \\
T9 & 100 & 0 & 3 \\
T10 & 200 & 3 & 0 \\
T11 & 200 & 0 & 0 \\
T12 & 200 & 0 & 3 \\
\hline
\end{tabular}

Two levels of $\mathrm{Si}(0 \& 3 \mathrm{mM})$ with two methods of Si applications ( $\mathrm{SiR} 3 \& \mathrm{SiF} 3)$ along with four levels of Cd@0,50,100, and $200 \mu \mathrm{M}$

\section{Determination of plant physiological traits}

Growth parameters like roots and shoots fresh and dry weights were measured after 100 days of germination. Two plants from each replication were sampled and stored at $80{ }^{\circ} \mathrm{C}$ in the freezer (Thermo Fisher Scientific, USA 702) for enzymatic analysis. Remaining plants were detached into root and shoots and were measured for their fresh weights (kept at $70{ }^{\circ} \mathrm{C}$ temperatures in the oven till constant dry weight), which were subsequently measured for $\mathrm{Si}, \mathrm{Cd}, \mathrm{K}^{+}$, total $\mathrm{N}$, and total protein contents.

\section{Measurements of photosynthetic pigments}

Photosynthetic pigments (carotenoids. Chlorophyll a, b, and total chlorophyll) were measured by an ultraviolet-visible spectrophotometer (TU-1810) using the spectrophotometric method of Metzner et al. (1965).

\section{Biochemical analysis}

Anti-oxidative enzymes like superoxide dismutase (SOD), catalase (CAT), guaiacol peroxidase (POD), of leaves were analyzed with ultraviolet visible spectrophotometer (TU-1810) by using the kits of Beijing Solarbio Science \& Technology Co., Ltd 
(http://www.solarbio.com). Briefly, $0.5 \mathrm{~g}$ weighted fresh samples of leaves were milled with the help of a motor and pestle and standardized in $0.05 \mathrm{M}$ phosphate buffer with pH 7.8 under chilled condition. The standardized mixture was centrifuged at 12,000 rpm for $10 \mathrm{~min}$ at $4{ }^{\circ} \mathrm{C}$ after sieving through four layers of muslin cloth.

The activity of CAT was measured by the following formula:

$$
C A T\left(\frac{\mu}{\text { mgprot }}\right)=\left(\text { OD }_{\text {control }}-O_{\text {Test }}\right) \times \frac{271}{60} \times \frac{1}{S Q} \times \frac{1}{\text { Proteinconc. }}
$$

where: $\mathrm{SQ}=$ sample quantity, $\mathrm{OD}_{\text {control }}=$ absorption of light in control, $\mathrm{OD}_{\text {test }}=$ absorption of light in test samples .

After mixing all reagents in the standardized mixture, the supernatant was again centrifuged at $3500 \mathrm{rpm}$ for $10 \mathrm{~min}$. The light diameter of $1 \mathrm{~cm}$ was adjusted to zero by double streaming water. OD was measured at $420 \mathrm{~nm}$ wavelength. The activity of POD was measured by the following equation:

$$
P O D\left(\frac{\mu}{m g p r o t}\right)=\left(O_{\text {Test }} \text { OD } \text { Control }\right) \times \frac{12}{1 \mathrm{~cm}} \times \frac{V_{t}}{S Q \times R T \times \text { Proteinconc. }} \times 1000 \text { (Eq.2) }
$$

where: $\mathrm{V}_{\mathrm{t}}=$ total volume of the reaction liquid, $\mathrm{SQ}=$ sample quantity, $\mathrm{RT}=$ reaction time, $\mathrm{OD}_{\text {control }}=$ absorption of light in control, $\mathrm{OD}_{\text {test }}=$ absorption of light in test samples.

After mixing all reagents in a standardized mixture, the supernatant was placed at room temperature for $10 \mathrm{~min}$. OD was measured at $550 \mathrm{~nm}$ wavelength. The activity of SOD was measured by the following equation:

$$
S O D\left(\frac{\mu}{\text { mgprot }}\right)=\left(\frac{O D_{\text {control }}-O D_{\text {test }}}{O D_{\text {Control }}}\right) \times \frac{1}{50} \times \frac{V_{t}}{S Q \times \text { Proteinconc } .}
$$

where: $V_{t}=$ total volume of the reaction liquid, $S Q=$ sample quantity, $\mathrm{OD}_{\text {control }}=$ absorption of light in control, $\mathrm{OD}_{\text {test }}=$ absorption of light in test samples .

The level of lipid peroxidation in the leaf tissue was assessed by measuring the contents of malondialdehyde (MDA, a by-product of lipid peroxidation. Briefly, 0.2$0.5 \mathrm{~g}$ weighted fresh samples of leaves were milled with the help of a motor and added $2 \mathrm{ml} \mathrm{10 \%} \mathrm{TCA} \mathrm{and} \mathrm{a} \mathrm{small} \mathrm{amount} \mathrm{of} \mathrm{quartz} \mathrm{sand,} \mathrm{ground} \mathrm{to} \mathrm{homogenate,} \mathrm{add} 3 \mathrm{ml}$ TCA, further ground. The homogenized sample was centrifuged at $12000 \mathrm{rpm}$ for $10 \mathrm{~min}$. Took $2 \mathrm{ml}$ supernatant, added $0.67 \%$ TBA, mixed and boiled for $15 \mathrm{~min}$ in $100{ }^{\circ} \mathrm{C}$ water bath. Cooled the sample at room temperature and centrifuged again. Absorption values of samples were measured at $532 \mathrm{~nm}, 600 \mathrm{~nm}$, and $450 \mathrm{~nm}$, respectively. The activity of MDA was measured by the following formula:

$$
\begin{gathered}
C M D A=6.45(A 532-A 600)-0.56 \times A 450 \\
M D A\left(\frac{\mu m o l}{g}\right)=C M D A \times\left(\frac{V_{t}}{S Q \times 1000}\right)
\end{gathered}
$$


where: $V_{t}=$ total volume of the reaction liquid, $S Q=$ sample quantity.

Proline was also assessed by using the kit of Beijing Solarbio Science \& Technology Co., Ltd. Following formula was used to measure the proline contents:

$$
\text { Proline }\left(\frac{\mu g}{g}\right)=\left(\frac{O D_{\text {sample }}-O D_{\text {blank }}}{O D_{\text {st }}-O D_{\text {blank }}}\right) \times C_{s t} \frac{5 \mu g}{m l} \times \frac{V_{\text {reagent }}}{M_{\text {tissue }}} \times C O D
$$

where: $\mathrm{CoD}=$ the coefficient of dilution in the pre-treatment process, $\mathrm{C}_{\mathrm{st}}=$ concentration of standard, $\mathrm{OD}_{\mathrm{st}}=$ absorption of standard sample.

Hydrogen peroxide levels in leaves of wheat plants were assessed by Sergiev et al. (1997) method (see Appendix heading 4).

\section{Translocation and bioaccumulation factors}

$\mathrm{Cd}$ translocation from shoot to root measured and calculated using the following equation:

$$
T F=\left(\frac{C_{\text {shoot }}}{C_{\text {root }}}\right)
$$

where $\mathrm{C}_{\text {shoot }}$ and $\mathrm{C}_{\text {root }}$ are the concentration of $\mathrm{Cd}$ in shoot and root, respectively. $\mathrm{TF}>1$ showed that metals effectively transported from root to shoot (Zhang et al., 2002).

The bioaccumulation factor (BAF) was calculated using the following equation:

$$
B A F=\left(\frac{C_{\text {shoot }}}{C_{\text {water }}}\right)
$$

where $\mathrm{C}_{\text {shoot }}$ and $\mathrm{C}$ water presented $\mathrm{Cd}$ concentration in shoot and water, respectively. BAF was categorizing further as hyperaccumulators samples, which accumulated metals $>1 \mathrm{mg} \mathrm{kg}^{-1}$, accumulator, and excluder samples, which accumulated metals $<1$ $\mathrm{mg} \mathrm{kg}^{-1}$ (Ma et al., 2001b).

\section{Determination of nutrient elements in plant tissues}

The $\mathrm{N}, \mathrm{K}^{+}, \mathrm{Cd}$, and $\mathrm{Si}$ content in the plants were analyzed by inductively coupled plasma mass spectroscopy (ICP-MS, Agilent, and $7700 \mathrm{X}$, USA) after being ovendried by following our previous study method (see Appendix heading 3) (Firat et al., 2017).

\section{Statistical analysis}

The data were processed and analyzed using the SPSS 21.0 (SPSS, Chicago, IL), and all the graphs were made using the Sigma plot 12.5 software packages. The means of the three replicates were subjected to analysis of variance (two-way ANOVA), and multiple comparisons were performed using Duncan's multiple range test (DMR) at $\mathrm{P}<0.05$. 


\section{Results}

\section{Cadmium attenuates growth parameters}

Cadmium (Cd) caused a significant decrease in plant biomass without Si application (Fig. 1). Plant biomass in $\mathrm{Cd} 50, \mathrm{Cd} 100$, and $\mathrm{Cd} 200$ was decreased by $42 \%$, 49\%, and $68 \%$, respectively, than that of the control plants. However, significantly higher biomass (root and shoot fresh weight) was recorded in Si treatments of combined SiR3 and SiF3 (Fig. 1). Plant biomass was increased, $71 \%, 62 \%$, and $119 \%$ respectively, in SiR $+\mathrm{Cd} 50, \mathrm{SiR}+\mathrm{Cd} 100$, and $\mathrm{SiR}+\mathrm{Cd} 200$ than that of the Cd50, Cd100 and Cd200. While, in $\mathrm{SiF}+\mathrm{Cd} 50, \mathrm{SiF}+\mathrm{Cd} 100$, and $\mathrm{SiF}+\mathrm{Cd} 200$ was increased, $45 \%, 40 \%$, and $101 \%$, respectively, than that of $\mathrm{Cd} 50, \mathrm{Cd} 100$, and $\mathrm{Cd} 200$. The maximum increase in plant biomass recorded in SiR3 while; minimum plant biomass was recorded in $\mathrm{Cd} 200$ than control (Fig. 1). Results showed that the overall SiR3 application performed well as compared to SiF3. Results showed that plant biomass in SiR3, SiR + Cd50, SiR $+\mathrm{Cd} 100$, and $\mathrm{SiR}+\mathrm{Cd} 200$ was $10 \%, 18 \%, 15 \%$, and $9 \%$, respectively than that $\mathrm{SiF} 3, \mathrm{SiF}+\mathrm{Cd} 50, \mathrm{SiF}+\mathrm{Cd} 100$, and $\mathrm{SiF}+\mathrm{Cd} 200$. Si concentration was found positively correlated with plant growth parameters (Fig. 2).

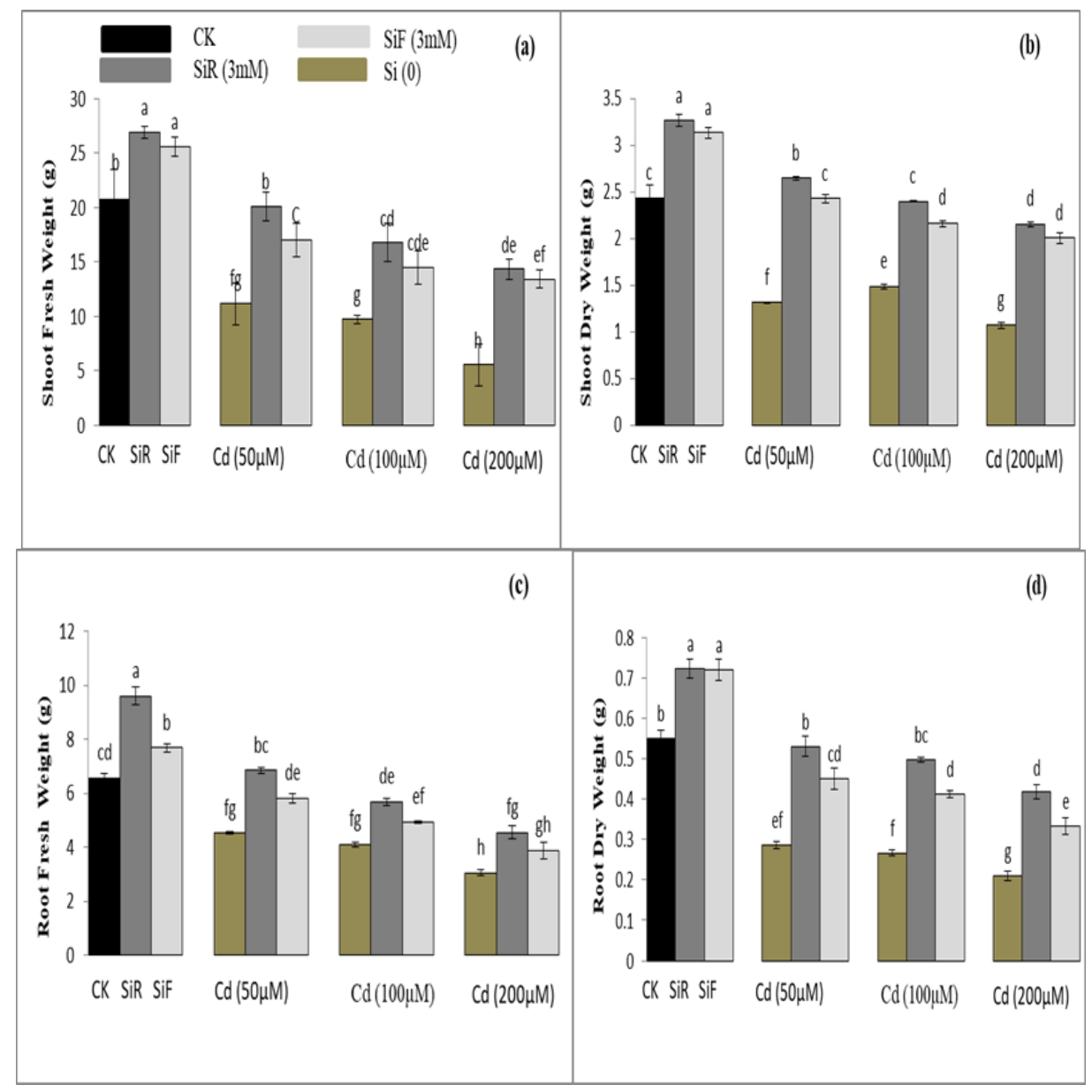

Figure 1. The effects of silicon application $(0,3 \mathrm{mM})$ on shoot fresh weight (a), shoot dry weight (b), root fresh weight (c) and root dry weight (d) of the wheat plant grown under 0,50 , 100 and $200 \mu M C d$ containing nutrient solution. Means $\pm S D(n=3)$ with different letters in column indicates significant $(p \leq 0.05)$ differences between treatments using Duncan's multiple range test (DMR) 

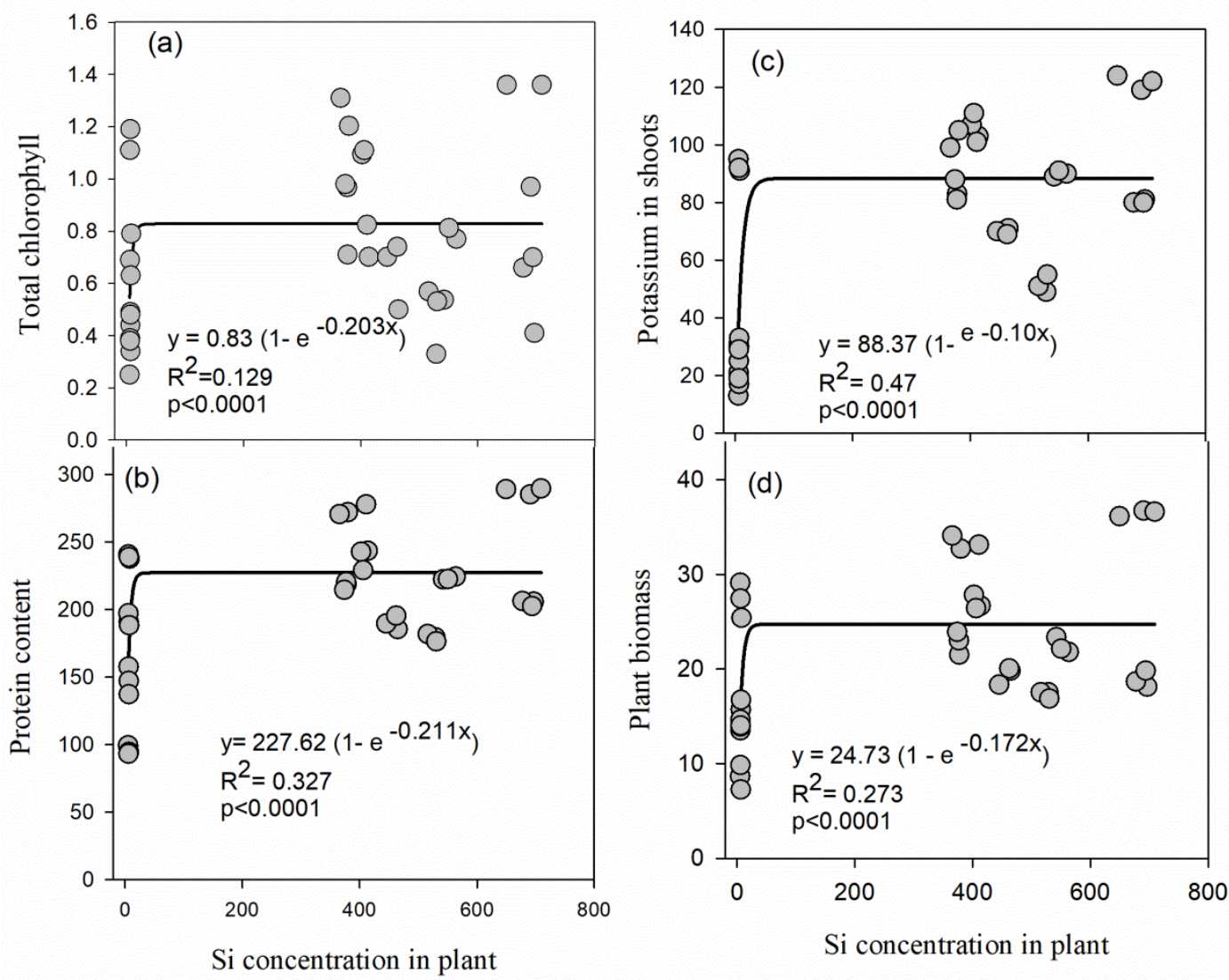

Figure 2. Relationships among Si concentration in plants with (a) total chlorophyll content (b) protein content $(c)$ potassium in plant and $(d)$ plant biomass

\section{Cadmium attenuates the photosynthetic pigments}

Cadmium $(\mathrm{Cd})$ stress triggered a significant $(\mathrm{p}<0.05)$ decline in carotenoids and total chlorophyll contents in wheat plants relative to control (Table 2). Total chlorophyll content in $\mathrm{Cd} 50, \mathrm{Cd} 100$, and $\mathrm{Cd} 200$ was decreased by $38 \%, 55 \%$, and $71 \%$ respectively, as compared to control. Similarly, carotenoids contents in Cd50 were only $38 \%$, while in $\mathrm{Cd} 100$ were $54 \%$ and in $\mathrm{Cd} 200$ were $71 \%$ compared to the control (Table 2). In the absence of $\mathrm{Cd}$, Si treatment as SiF3 and SiR3 significantly $(\mathrm{p}<0.05)$ elevated carotenoids and total chlorophyll contents. For instance, total chlorophyll contents in $\mathrm{SiR}+\mathrm{Cd} 50$ were $34 \%$ that of $\mathrm{Cd} 50$, while, in $\mathrm{SiR}+\mathrm{Cd} 100$ were $30 \%$ that of $\mathrm{Cd} 100$ and in $\mathrm{SiR}+\mathrm{Cd} 200$ were $123 \%$ that of the $\mathrm{Cd} 200$. Correlation analysis was done between the means of the total concentration of $\mathrm{Si}$ in plant and total chlorophyll content, which showed a significantly $(\mathrm{p}<0.05)$ positive correlation (Fig. 2). Similarly, carotenoids contents in $\mathrm{SiR}+\mathrm{Cd} 50$ were $67 \%$ higher than $\mathrm{Cd} 50$, while, in $\mathrm{SiR}+\mathrm{Cd} 100$ were $69 \%$ higher than $\mathrm{Cd} 100$ and in $\mathrm{SiR}+\mathrm{Cd} 200$ were $83 \%$ higher than $\mathrm{Cd} 200$, respectively. Moreover, total chlorophyll contents in $\mathrm{SiF}+\mathrm{Cd} 50$ were $43 \%$ higher than Cd50, while in $\mathrm{SiF}+\mathrm{Cd} 100$ were $58 \%$ higher than $\mathrm{Cd} 100$ and in $\mathrm{SiF}+\mathrm{Cd} 200$ were 90\% higher than Cd200 respectively. Furthermore, the significant increase in total chlorophyll contents observed in $\mathrm{SiF} 3$ as compared to $\mathrm{SiR} 3$. For instance, total chlorophyll contents in $\mathrm{SiF}+\mathrm{Cd} 50$ were $6 \%$ higher than $\mathrm{SiR}+\mathrm{Cd} 50$, while in $\mathrm{SiF}$ $+\mathrm{Cd} 100$ were $18 \%$ higher than $\mathrm{SiR}+\mathrm{Cd} 100$, and in $\mathrm{SiF}+\mathrm{Cd} 200$ were $17 \%$ higher than 
$\mathrm{SiR}+\mathrm{Cd} 200$ respectively. Contradictory results recorded in carotenoids content like maximum carotenoids contents observed in SiR3 than SiF3. Carotenoids contents in $\mathrm{SiR}+\mathrm{Cd} 50$ were $29 \%$ higher than $\mathrm{SiF}+\mathrm{Cd} 50$, while in $\mathrm{SiR}+\mathrm{Cd} 100$ were $146 \%$ higher than $\mathrm{SiF}+\mathrm{Cd} 100$, and in $\mathrm{SiR}+\mathrm{Cd} 200$ were $66 \%$ higher than $\mathrm{SiF}+\mathrm{Cd} 200$, respectively (Table 2).

Table 2. Effect of different concentration of $C d(0,50,100$, and $200 \mu M)$ and Silica sol. (0, $3 \mathrm{mM}$ ) along with different methods of Si application on chlorophyll contents of the wheat crop

\begin{tabular}{c|c|c|c|c}
\hline Treatments & Chl a $(\mathbf{m g} / \mathbf{g})$ & Chl b $(\mathbf{m g} / \mathbf{g})$ & Total Chl $(\mathbf{m g} / \mathbf{g})$ & Carotenoids $(\mathbf{m g} / \mathbf{g})$ \\
\hline $\mathrm{Ck}$ & $0.80 \pm 0.005^{\mathrm{bc}}$ & $0.34 \pm 0.03^{\mathrm{abc}}$ & $1.03 \pm 0.12^{\mathrm{abc}}$ & $0.65 \pm 0.02^{\mathrm{ab}}$ \\
$\mathrm{SiR} 3 \mathrm{mM}$ & $0.94 \pm 0.017^{\mathrm{a}}$ & $0.42 \pm 0.02^{\mathrm{a}}$ & $1.23 \pm 0.13^{\mathrm{a}}$ & $0.83 \pm 0.05^{\mathrm{a}}$ \\
$\mathrm{SiF} 3 \mathrm{mM}$ & $0.85 \pm 0.030^{\mathrm{b}}$ & $0.39 \pm 0.01^{\mathrm{ab}}$ & $1.11 \pm 0.15^{\mathrm{ab}}$ & $0.71 \pm 0.04^{\mathrm{ab}}$ \\
$\mathrm{Cd} 50 \mu \mathrm{M}$ & $0.44 \pm 0.014^{\mathrm{fg}}$ & $0.22 \pm 0.01^{\mathrm{de}}$ & $0.59 \pm 0.08^{\mathrm{ef}}$ & $0.34 \pm 0.02^{\mathrm{de}}$ \\
$\mathrm{SiR} 3+\mathrm{Cd} 50$ & $0.75 \pm 0.02^{\mathrm{cd}}$ & $0.32 \pm 0.01^{\mathrm{bc}}$ & $0.97 \pm 0.13^{\mathrm{bc}}$ & $0.57 \pm 0.01^{\mathrm{bc}}$ \\
$\mathrm{SiF} 3+\mathrm{Cd} 50$ & $0.70 \pm 0.00^{5 \mathrm{~d}}$ & $0.26 \pm 0.02^{\mathrm{cd}}$ & $0.89 \pm 0.09^{\mathrm{cd}}$ & $0.55 \pm 0.21^{\mathrm{bc}}$ \\
$\mathrm{Cd} 100 \mu \mathrm{M}$ & $0.36 \pm 0.015^{\mathrm{g}}$ & $0.16 \pm 0.02^{\mathrm{ef}}$ & $0.45 \pm 0.03^{\mathrm{fg}}$ & $0.26 \pm 0.01^{\mathrm{de}}$ \\
$\mathrm{SiR} 3+\mathrm{Cd} 100$ & $0.51 \pm 0.013^{\mathrm{ef}}$ & $0.27 \pm 0.02^{\mathrm{cd}}$ & $0.71 \pm 0.09^{\mathrm{de}}$ & $0.44 \pm 0.08^{\mathrm{cd}}$ \\
$\mathrm{SiF} 3+\mathrm{Cd} 100$ & $0.50 \pm 0.005^{\mathrm{ef}}$ & $0.21 \pm 0.02^{\mathrm{de}}$ & $0.65 \pm 0.07^{\mathrm{ef}}$ & $0.41 \pm 0.02^{\mathrm{cd}}$ \\
$\mathrm{Cd} 200 \mu \mathrm{M}$ & $0.27 \pm 0.011^{\mathrm{h}}$ & $0.08 \pm 0.01^{\mathrm{f}}$ & $0.32 \pm 0.04^{\mathrm{g}}$ & $0.18 \pm 0.01 \mathrm{e}^{\mathrm{d}}$ \\
$\mathrm{SiR} 3+\mathrm{Cd} 200$ & $0.41 \pm 0.014^{\mathrm{e}}$ & $0.26 \pm 0.01^{\mathrm{cd}}$ & $0.73 \pm 0.09^{\mathrm{de}}$ & $0.33 \pm 0.03^{\mathrm{de}}$ \\
$\mathrm{SiF} 3+\mathrm{Cd} 200$ & $0.37 \pm 0.023^{\mathrm{g}}$ & $0.17 \pm 0.02^{\mathrm{e}}$ & $0.48 \pm 0.07^{\mathrm{fg}}$ & $0.28 \pm 0.01^{\mathrm{de}}$ \\
\hline
\end{tabular}

Values show the means of three replications \pm SD. Means followed by same small letters are not significantly different at $\mathrm{P} \leq 0.05$ by using the Duncan's multiple range test (DMR)

\section{Cadmium accumulation in the wheat plant}

Results showed that Cd content significantly enhanced when plants received $\mathrm{Cd}$ stress relative to control. Silicon $(3 \mathrm{mM})$ addition as $\mathrm{SiR} 3$ and $\mathrm{SiF} 3$ significantly reduced $\mathrm{Cd}$ concentration in all parts of the plant, and the effect was more significant in $\mathrm{SiR} 3$ than $\mathrm{SiF} 3$. Moreover, results exhibited that $\mathrm{Cd}$ concentration in $\mathrm{SiR}+\mathrm{Cd} 50$ was $25 \%$ less than $\mathrm{SiF}+\mathrm{Cd} 50$, while in $\mathrm{SiR}+\mathrm{Cd} 100$ was $25 \%$ less than $\mathrm{SiF}+\mathrm{Cd} 100$, and $\mathrm{SiR}+\mathrm{Cd} 200$ was $32 \%$ less than $\mathrm{SiF}+\mathrm{Cd} 200$ in shoot (Table 2). Whereas, $\mathrm{Cd}$ concentration in $\mathrm{SiR}+\mathrm{Cd} 50$ was $27 \%$ higher than $\mathrm{SiF}+\mathrm{Cd} 50$, while $\mathrm{SiR}+\mathrm{Cd} 100$ was $10 \%$ higher than $\mathrm{SiF}+\mathrm{Cd} 100$, and $\mathrm{SiR}+\mathrm{Cd} 200$ was $21 \%$ higher than $\mathrm{SiF}+\mathrm{Cd} 200$ in root (Table 3). Both Si treatments minimized $\mathrm{Cd}$ accumulation significantly, but SiR3 bound more $\mathrm{Cd}$ in root cells and restricted its translocation from root to shoot and detoxify its deleterious effects more efficiently than Si foliar-application (Table 3).

Table 3. Effect of different concentration of silica sol. $(0,3 \mathrm{mM})$ along with different methods of application and $C d(0,50,100$ and $200 \mu \mathrm{M})$ on $\mathrm{Cd}$ and Si accumulation in wheat crop

\begin{tabular}{c|c|c|c|c}
\hline Treatments & $\begin{array}{c}\text { Cd accumulation } \\
(\boldsymbol{\mu g} / \mathbf{g}) \text { in root }\end{array}$ & $\begin{array}{c}\text { Cd accumulation } \\
(\boldsymbol{\mu g} / \mathbf{g}) \text { in shoot }\end{array}$ & $\begin{array}{c}\text { Si accumulation } \\
(\boldsymbol{\mu g} / \mathbf{g}) \text { in root }\end{array}$ & $\begin{array}{c}\text { Si accumulation } \\
(\boldsymbol{\mu g} / \mathbf{g}) \text { in shoot }\end{array}$ \\
\hline $\mathrm{Ck}$ & $5.07 \pm 0.1^{\mathrm{j}}$ & $0.04 \pm 0.02^{\mathrm{i}}$ & $2.57 \pm 0.2^{\mathrm{g}}$ & $4.11 \pm 0.5^{\mathrm{d}}$ \\
$\mathrm{SiR} 3 \mathrm{mM}$ & $0.70 \pm 0.1^{\mathrm{j}}$ & $0.03 \pm 0.01^{\mathrm{i}}$ & $423.11 \pm 5.9^{\mathrm{d}}$ & $139.88 \pm 9.2^{\mathrm{c}}$ \\
$\mathrm{SiF} 3 \mathrm{mM}$ & $0.53 \pm 0.1^{\mathrm{j}}$ & $0.02 \pm 0.005^{\mathrm{i}}$ & $85.98 \pm 3.6^{\mathrm{ef}}$ & $299.55 \pm 16.5^{\mathrm{a}}$
\end{tabular}




\begin{tabular}{c|c|c|c|c}
$\mathrm{Cd} 50 \mu \mathrm{M})$ & $1696.84 \pm 40.6^{\mathrm{e}}$ & $1112.103 \pm 7.1^{\mathrm{c}}$ & $3.17 \pm 0.2^{\mathrm{g}}$ & $3.27 \pm 0.3^{\mathrm{d}}$ \\
$\mathrm{SiR} 3+\mathrm{Cd} 50$ & $837.89 \pm 9.4^{\mathrm{h}}$ & $229.1 \pm 2.8^{\mathrm{h}}$ & $660.05 \pm 6.0^{\mathrm{c}}$ & $130.98 \pm 7.1^{\mathrm{c}}$ \\
$\mathrm{SiF} 3+\mathrm{Cd} 50$ & $659.50 \pm 4.63^{\mathrm{i}}$ & $309.57 \pm 12.3^{\mathrm{g}}$ & $93.15 \pm 2.9^{\mathrm{ef}}$ & $213.48 \pm 5.9^{\mathrm{a}}$ \\
$\mathrm{Cd} 100 \mu \mathrm{M}$ & $2335.95 \pm 18.7^{\mathrm{c}}$ & $1313.89 \pm 9.9^{\mathrm{b}}$ & $3.25 \pm 0.1^{\mathrm{g}}$ & $3.00 \pm 0.2^{\mathrm{d}}$ \\
$\mathrm{SiR} 3+\mathrm{Cd} 100$ & $1347.83 \pm 21.9^{\mathrm{f}}$ & $453.38 \pm 23.3^{\mathrm{f}}$ & $797.88 \pm 13.2^{\mathrm{b}}$ & $125.85 \pm 3.7^{\mathrm{c}}$ \\
$\mathrm{SiF} 3+\mathrm{Cd} 100$ & $1216.36 \pm 10.1^{\mathrm{g}}$ & $605.09 \pm 7.9^{\mathrm{e}}$ & $101.78 \pm 5.2 \mathrm{e}$ & $210.68 \pm 6.1^{\mathrm{d}}$ \\
$\mathrm{Cd} 200 \mu \mathrm{M}$ & $3654.55 \pm 7.3^{\mathrm{a}}$ & $1936.27 \pm 26.4^{\mathrm{a}}$ & $3.07 \pm 0.1^{\mathrm{g}}$ & $2.87 \pm 0.3^{\mathrm{d}}$ \\
$\mathrm{SiR} 3+\mathrm{Cd} 200$ & $2037.04 \pm 42.7^{\mathrm{b}}$ & $657.42 \pm 23.6 \mathrm{~b}^{\mathrm{d}}$ & $997.64 \pm 6.9^{\mathrm{a}}$ & $117.03 \pm 2.5^{\mathrm{c}}$ \\
$\mathrm{SiF} 3+\mathrm{Cd} 200$ & $2474.82 \pm 8.3^{\mathrm{b}}$ & $978.08 \pm 11.4^{\mathrm{c}}$ & $63.97 \pm 15.8^{\mathrm{f}}$ & $281.45 \pm 5.9^{\mathrm{b}}$ \\
\hline
\end{tabular}

Values show the means of three replications \pm S.D. Means by the same small letters are not significantly different at $\mathrm{P}<0.05$ by using the Duncan's multiple range test (DMR)

\section{Silicon attenuates translocation factor and bioaccumulation factor of Cd}

Results showed that a significant $(\mathrm{p}<0.05)$ positive correlation was recorded between $\mathrm{Cd}$ concentration and translocation factor (TF) (Table 4), which means $\mathrm{Cd}$ translocation factor increased with the rise of $\mathrm{Cd}$ levels in the nutrient solution. While $\mathrm{Si}$ application as $\mathrm{SiR} 3$ and $\mathrm{SiF} 3$ both minimized $\mathrm{Cd}$ translocation from root to shoot, but more significant results observed in case of $\mathrm{SiR} 3$. TF of $\mathrm{Cd}$ in $\mathrm{SiR}+\mathrm{Cd} 50$ was $41 \%$ less than $\mathrm{SiF}+\mathrm{Cd} 50$, while in $\mathrm{SiR}+\mathrm{Cd} 100$ was $32 \%$ less than $\mathrm{SiF}+\mathrm{Cd} 100$, and in $\mathrm{SiR}$ $+\mathrm{Cd} 200$ was $33 \%$ less than $\mathrm{SiF}+\mathrm{Cd} 200$, respectively. Moreover, in both SiR3 and $\mathrm{SiF} 3, \mathrm{TF}<1$ showed $\mathrm{Cd}$ incompetently transport from root to shoot in a wheat plant in the presence of $\mathrm{Si}$. In the case of $\mathrm{Cd}$, bioaccumulation factor recorded data showed significantly $(\mathrm{p}<0.05)$ negative correlation between BAF of $\mathrm{Cd}$ and Cd existence in the nutrient solution (Table 5). Silicon both applications SiR3 or SiF3 showed a significantly negative correlation with both $\mathrm{Cd}$ bioaccumulation and translocation factors (Fig. 4). Moreover, Si treatments as SiR3 and SiF3 along with Cd (50, 100, and $200 \mu \mathrm{M}$ ) further minimized BAF of $\mathrm{Cd}$, but results were more significant in SiR3 as compared to $\mathrm{SiF} 3$. For instance, $\mathrm{BAF}$ of $\mathrm{Cd}$ in $\mathrm{SiR}+\mathrm{Cd} 50$ was $26 \%$ less than $\mathrm{SiF}$ $+\mathrm{Cd} 50$, while in $\mathrm{SiR}+\mathrm{Cd} 100$ was $25 \%$ less than $\mathrm{SiF}+\mathrm{Cd} 100$, and in $\mathrm{SiR}+\mathrm{Cd} 200$ was $33 \%$ less than $\mathrm{F} 3+\mathrm{Cd} 200$ respectively (Table 4$)$.

Table 4. Effect of different application methods as well as levels of Si on Cd translocation and bioaccumulation factors

\begin{tabular}{c|c|c}
\hline Treatments & Translocation factor $(\%)$ & Bioaccumulation factor $(\%)$ \\
\hline Ck & $0.007 \pm 0.003^{\mathrm{f}}$ & $0 \pm 0^{\mathrm{g}}$ \\
$\mathrm{SiR} 3 \mathrm{mM}$ & $0.004 \pm 0.012^{\mathrm{f}}$ & $0 \pm 0^{\mathrm{g}}$ \\
$\mathrm{SiF} 3 \mathrm{mM}$ & $0.05 \pm 0.025^{\mathrm{f}}$ & $0 \pm 0^{\mathrm{g}}$ \\
$\mathrm{Cd} 5 \mu \mathrm{M}$ & $0.65 \pm 0.011^{\mathrm{a}}$ & $0.121 \pm 0.0007^{\mathrm{a}}$ \\
$\mathrm{SiR} 3+\mathrm{Cd} 50$ & $0.27 \pm 0.003^{\mathrm{e}}$ & $0.025 \pm 0.0003^{\mathrm{e}}$ \\
$\mathrm{SiF} 3+\mathrm{Cd} 50$ & $0.47 \pm 0.001^{\mathrm{c}}$ & $0.034 \pm 0.001^{\mathrm{d}}$ \\
$\mathrm{Cd} 100 \mu \mathrm{M}$ & $0.56 \pm 0.008^{\mathrm{b}}$ & $0.072 \pm 0.0005^{\mathrm{b}}$ \\
$\mathrm{SiR} 3+\mathrm{Cd} 100$ & $0.34 \pm 0.021^{\mathrm{de}}$ & $0.025 \pm 0.001^{\mathrm{e}}$ \\
$\mathrm{SiF} 3+\mathrm{Cd} 100$ & $0.49 \pm 0.01^{\mathrm{bc}}$ & $0.033 \pm 0.0004^{\mathrm{d}}$ \\
$\mathrm{Cd} 200 \mu \mathrm{M}$ & $0.55 \pm 0.006^{\mathrm{bc}}$ & $0.053 \pm 0.0007^{\mathrm{c}}$ \\
$\mathrm{SiR} 3+\mathrm{Cd} 200$ & $0.32 \pm 0.017^{\mathrm{e}}$ & $0.018 \pm 0.0006^{\mathrm{f}}$ \\
$\mathrm{SiF} 3+\mathrm{Cd} 200$ & $0.39 \pm 0.005^{\mathrm{d}}$ & $0.027 \pm 0.0003^{\mathrm{e}}$ \\
\hline
\end{tabular}

Values show the means of three replications \pm SD. Means followed by same small letters are not significantly different at $\mathrm{P} \leq 0.05$ by using the Duncan's multiple range test (DMR) 


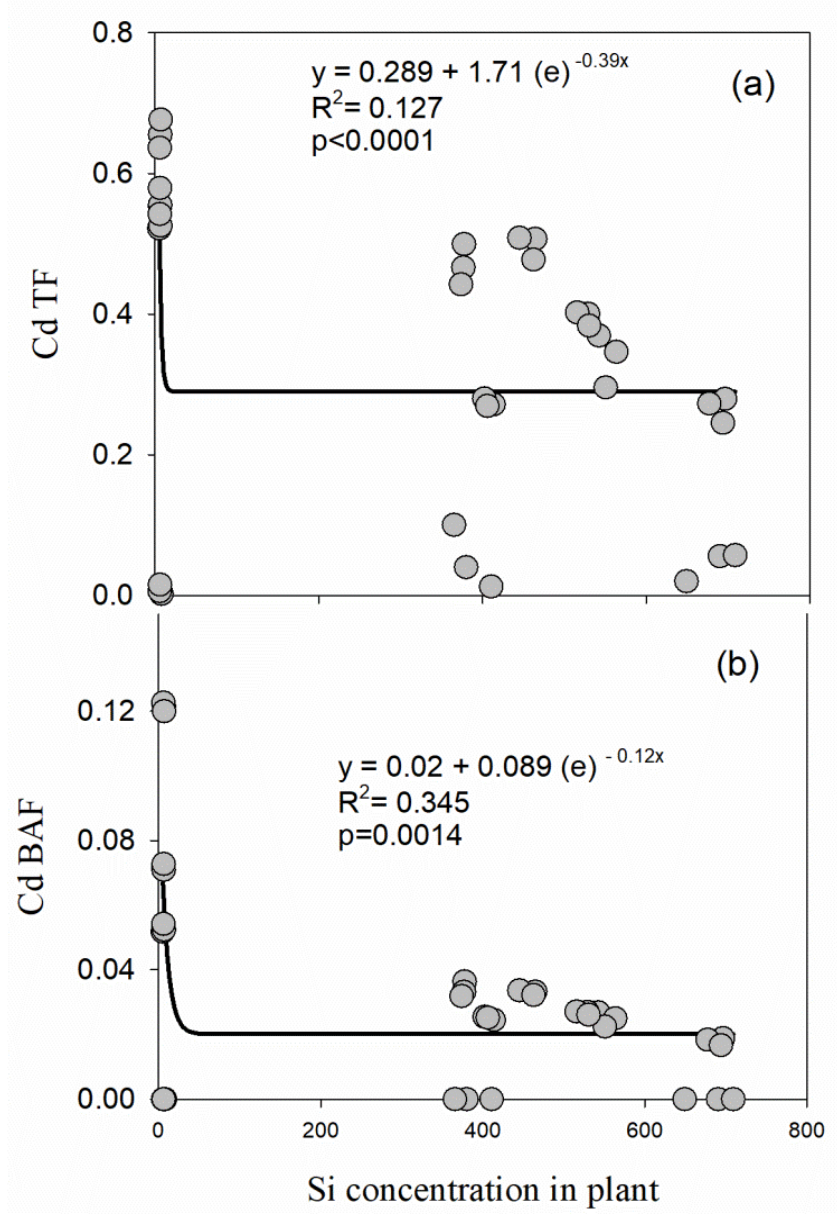

Figure 4. The relationship among Si concentration in the plant, cadmium translocation factor $(C d T F)$, and cadmium bioaccumulation factor $(C d B A F)$

\section{Silicon accumulation under cadmium toxicity}

Silicon concentration was significantly $(\mathrm{p}<0.05)$ increased when plants exposed to $\mathrm{Si}$ treatments as $\mathrm{SiF} 3$ and $\mathrm{SiR} 3$ relative to the control. Si concentration in SiF3 application was higher in shoots as compared to $\mathrm{SiR} 3$ application. For instance, $\mathrm{Si}$ concentration in $\mathrm{SiF}+\mathrm{Cd} 50$ was $62 \%$ higher than in the $\mathrm{SiR}+\mathrm{Cd} 50$, while, in $\mathrm{SiF}$ + Cd100 was $33 \%$ higher than in the $\mathrm{SiR}+\mathrm{Cd} 100$, and in $\mathrm{SiF}+\mathrm{Cd} 200$ was $31 \%$ higher than in the $\mathrm{SiR}+\mathrm{Cd} 200$ respectively. While in SiR3 application, Si concentration in $\mathrm{SiR} 3$ was higher in root than shoot as compared to SiF3 application. For instance, our results showed that, $\mathrm{Si}$ concentration in $\mathrm{SiR}+\mathrm{Cd} 50$ was $70 \%$ higher than in the $\mathrm{SiF}$ $+\mathrm{Cd} 50$, while, in $\mathrm{SiR}+\mathrm{Cd} 100$ was $129 \%$ higher than in the $\mathrm{SiF}+\mathrm{Cd} 100$, and in $\mathrm{SiR}$ $+\mathrm{Cd} 200$ was $189 \%$ higher than in the $\mathrm{SiF}+\mathrm{Cd} 200$ respectively in root. The recorded data showed that $\mathrm{Si}$ concentration increased with the increase in Cd levels (Table 3). Si accumulation in root was more significant in $\mathrm{SiR} 3$ as relatively $\mathrm{SiF} 3$ while, $\mathrm{Si}$ accumulation in the shoot was more significant in SiF3 as relatively SiR3 (Table 3).

\section{Cadmium enhances reactive oxygen species (ROS)}

A significantly higher concentration of $\mathrm{H}_{2} \mathrm{O}_{2}$ and MDA in the shoot was recorded in Cd-treated plants than control (Fig. 3b). 


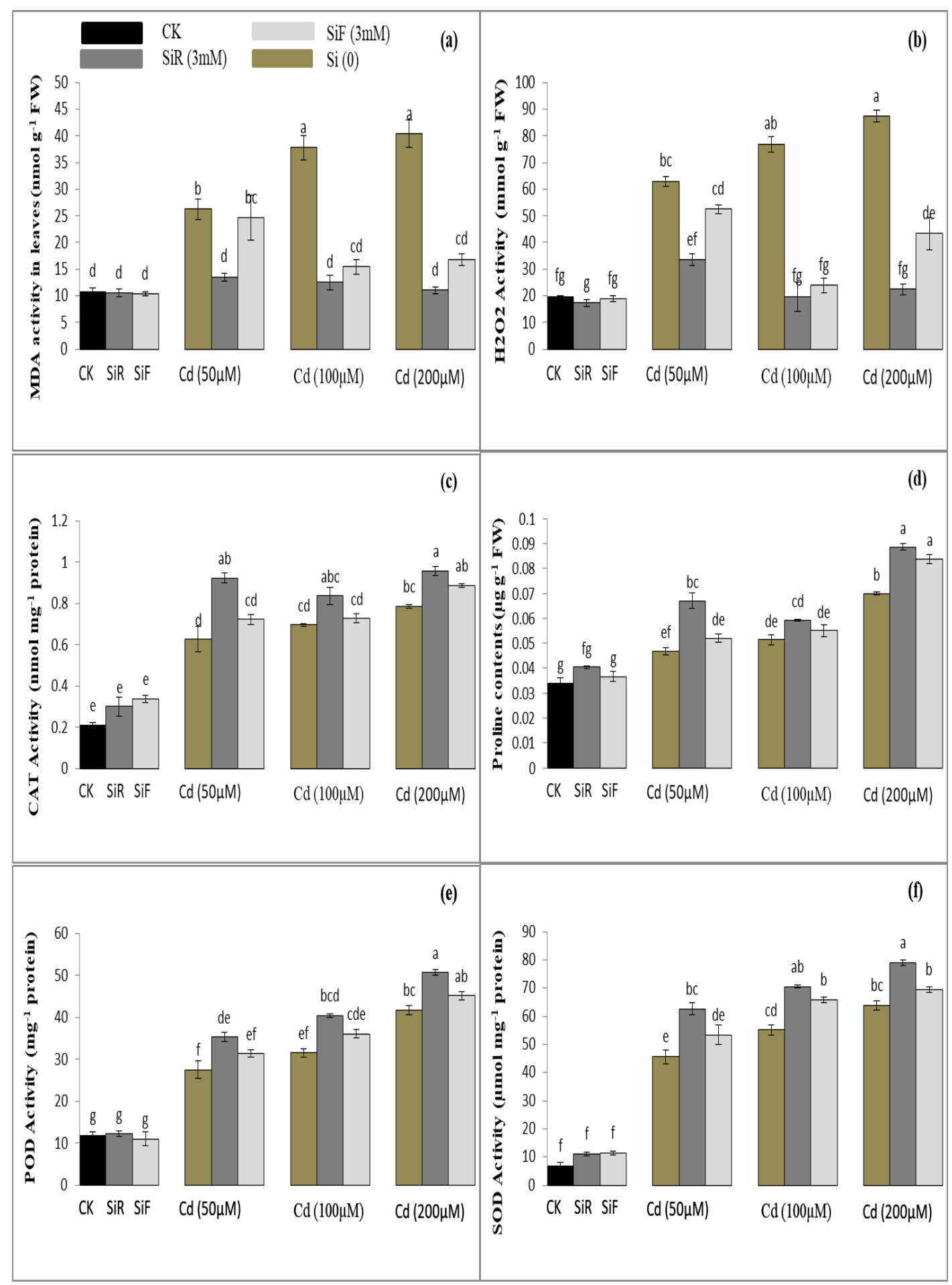

Figure 3. The effects of silicon application $(0,3 \mathrm{mM})$ on reactive oxygen species (ROS) activity i.e. $\mathrm{MDA}(\mathrm{a}), \mathrm{H}_{2} \mathrm{O}_{2}(b)$, and antioxidative enzymes activity i.e. CAT (c), proline (d), $\mathrm{POD}(\mathrm{e})$ and SOD (f) of the wheat plant grown under 0, 50, 100 and $200 \mu \mathrm{MCd}$ containing nutrient solution. Bars show S.E. of three replications, the different letter above column within CAT, $S O D, P O D, M D A, \mathrm{H}_{2} \mathrm{O}_{2}$, and proline represents a significant difference at $P<0.05$ by using Duncan's multiple range test (DMR) 
For instance, $\mathrm{H}_{2} \mathrm{O}_{2}$ concentration was $219 \%$ higher in $\mathrm{Cd} 50$, was $290 \%$ higher in $\mathrm{Cd} 100$, and was 343\% higher in Cd200 than in control, respectively. Si application as SiR3 and SiF3 significantly $(\mathrm{P}<0.05)$ decreased the concentration of $\mathrm{H}_{2} \mathrm{O}_{2}$ in shoots $($ Fig. $3 b)$, but $\mathrm{SiR} 3$ proved more effective than $\mathrm{SiF} 3$. For instance, $\mathrm{H}_{2} \mathrm{O}_{2}$ concentration in SiR3 $+\mathrm{Cd} 50$ was $36 \%$ lower than in the $\mathrm{SiF} 3+\mathrm{Cd} 50$, while in $\mathrm{SiR}+\mathrm{Cd} 100$ was $17 \%$ lower than in $\mathrm{SiF}+\mathrm{Cd} 100$, and in the $\mathrm{SiR}+\mathrm{Cd} 200$ was $48 \%$ lower than in the $\mathrm{SiF}+\mathrm{Cd} 200$ respectively (Fig. 3b). The same trend recorded in MDA contents. MDA concentration was significantly high in Cd-treated shoots as being compared to control. For instance, MDA concentration was, respectively, $144 \%, 251 \%$, and $276 \%$ in $\mathrm{Cd} 50, \mathrm{Cd} 100$, and $\mathrm{Cd} 200$ that of the control (Fig. 3a). Added Si as SiR3 and SiF3 significantly lower MDA concentration in shoots of wheat plants at all Cd supply levels (Fig. 3a), but the maximum decreased in MDA concentration was noted in SiR3-treated plants along with or without $\mathrm{Cd} 50, \mathrm{Cd} 100$, and $\mathrm{Cd} 200$ as compared to all other treatments. For instance, MDA concentration was $45 \%, 18 \%$, and $34 \%$ lower in $\mathrm{SiR}+\mathrm{Cd} 50, \mathrm{SiR}+\mathrm{Cd} 100$, and $\mathrm{SiR}+\mathrm{Cd} 200$ that of the $\mathrm{SiF}+\mathrm{Cd} 50, \mathrm{SiF}+\mathrm{Cd} 100$, and $\mathrm{SiF}+\mathrm{Cd} 200$ respectively (Fig. $3 a)$.

\section{Cadmium meliorates enzymatic and non-enzymatic antioxidants in wheat seedlings}

A significant elevation was recorded in enzymatic (superoxide dismutase; SOD, peroxidase; POD and catalase; CAT) and non-enzymatic (proline) antioxidants concentration in Cd-treated plants as being compared to control. For instance, SOD activity was, 568\%, 708\%, 835\% higher respectively, POD activity was $133 \%, 166 \%$, $253 \%$ higher respectively, CAT activity was $198 \%, 231 \%, 275 \%$ higher respectively, and proline concentration was $37 \%, 51 \%, 106 \%$ higher in $\mathrm{Cd} 50, \mathrm{Cd} 100$, and $\mathrm{Cd} 200$ that of the control (Fig. 3c, d,e,f). Added Si as SiF3 and SiR3 further elevated SOD, POD, CAT, and proline activities significantly with or without Cd50, Cd100, and $\mathrm{Cd} 200$. Overall, SiR3 alone, as well as with Cd50, Cd100, and Cd200 performed well to boost up $\mathrm{SOD}, \mathrm{POD}, \mathrm{CAT}$, and proline activities as compared to $\mathrm{SiF} 3$, but the difference was not significant. For instance, POD activity in SiR3 along with Cd (50, 100 and $200 \mu \mathrm{mol} / \mathrm{L})$ was $31 \%, 36 \%, 45 \%$ respectively, SOD activity was $17 \%, 7 \%$, and $14 \%$ higher, CAT activity was $27 \%, 15 \%$, and $8 \%$ higher, and proline concentration was $28 \%, 8 \%$, and $6 \%$ higher than that of higher than of SiF3 along with same levels of Cd (Fig. 3).

\section{Cadmium attenuate essential nutrients in wheat}

A significant decreasing trend was recorded in $\mathrm{K}^{+}$and $\mathrm{N}$ concentration in $\mathrm{Cd}$ stressed plants than that of control (Table 5). For instance, $\mathrm{K}^{+}$and $\mathrm{N}$ concentration was, $66 \%$ and $73 \%, 82 \%$ and $19 \%, 38 \%, 59 \%$ respectively, in $\mathrm{Cd} 50, \mathrm{Cd} 100$, and $\mathrm{Cd} 200$ that of the control. Added Si as SiF3 and SiR3 alone, as well as with Cd50, Cd100, and $\mathrm{Cd} 200$, significantly increased $\mathrm{K}^{+}$and $\mathrm{N}$ concentration in the shoot of the wheat plant (Table 5). The maximum increase in results recorded in case of $\mathrm{SiR} 3$ compared to $\mathrm{SiF} 3$. For instance, $\mathrm{K}^{+}$and $\mathrm{N}$ concentration in shoot was, respectively, 27\%, 28\%, 55\% and $24 \%, 51 \%, 113 \%$ higher in $\mathrm{SiR}+\mathrm{Cd} 50, \mathrm{SiR}+\mathrm{Cd} 100$, and $\mathrm{SiR}+\mathrm{Cd} 200$ that of the $\mathrm{SiF}$ $+\mathrm{Cd} 50, \mathrm{SiF}+\mathrm{Cd} 100$, and $\mathrm{SiF}+\mathrm{Cd} 200$. Total $\mathrm{Si}$ concentration in plant showed a strong affirmative association with $\mathrm{K}^{+}$concentration in shoots of wheat plants (Fig. 2). With the increase of $\mathrm{Si}$ concentration from 0 to $3 \mathrm{mM}$ significantly increased $\mathrm{K}^{+}$ concentration from $16 \mathrm{mg} \mathrm{g}^{-1}$ to $107 \mathrm{mg} \mathrm{g}^{-1}$ (Table 5). 
Table 5. Effect of different concentrations of $C d(0,50,100$, and $200 \mu \mathrm{M})$, and Silica sol. $(0$ and $3 \mathrm{mM}$ ) along with different ways of Si application on $\mathrm{K}^{+}$, total $N$ and total Protein concentration in shoots of the wheat plant

\begin{tabular}{c|c|c|c}
\hline Treatments & $\begin{array}{c}\mathbf{K}^{+} \text {concentration in shoot } \\
(\mathbf{m g} / \mathbf{g})\end{array}$ & $\begin{array}{c}\text { Total N in shoot } \\
(\mathbf{m g} / \mathbf{g})\end{array}$ & $\begin{array}{c}\text { Total protein in shoot } \\
(\mathbf{m g} / \mathbf{g})\end{array}$ \\
\hline $\mathrm{Ck}$ & $92.67 \pm 1.20^{\mathrm{c}}$ & $38.25 \pm 0.15^{\mathrm{c}}$ & $239.06 \pm 0.93^{\mathrm{c}}$ \\
$\mathrm{SiR} 3 \mathrm{mM}$ & $121.67 \pm 1.45^{\mathrm{a}}$ & $46.07 \pm 0.22^{\mathrm{a}}$ & $287.96 \pm 1.36^{\mathrm{a}}$ \\
$\mathrm{SiF} 3 \mathrm{mM}$ & $101.67 \pm 1.76^{\mathrm{b}}$ & $43.75 \pm 0.35^{\mathrm{b}}$ & $273.44 \pm 2.21^{\mathrm{b}}$ \\
$\mathrm{Cd} 50 \mu \mathrm{M}$ & $31.33 \pm 0.88^{\mathrm{h}}$ & $30.73 \pm 0.43^{\mathrm{fg}}$ & $192.08 \pm 2.68^{\mathrm{fg}}$ \\
$\mathrm{SiR} 3+\mathrm{Cd} 50$ & $107.00 \pm 2.31^{\mathrm{b}}$ & $38.15 \pm 0.74^{\mathrm{c}}$ & $238.41 \pm 4.64^{\mathrm{c}}$ \\
$\mathrm{SiF} 3+\mathrm{Cd} 50$ & $84.00 \pm 2.08^{\mathrm{de}}$ & $34.86 \pm 0.27^{\mathrm{de}}$ & $217.84 \pm 1.70^{\mathrm{de}}$ \\
$\mathrm{Cd} 100 \mu \mathrm{M}$ & $25.00 \pm 2.31^{\mathrm{h}}$ & $23.57 \pm 0.94^{\mathrm{h}}$ & $147.32 \pm 5.88^{\mathrm{h}}$ \\
$\mathrm{SiR} 3+\mathrm{Cd} 100$ & $90.00 \pm 0.58^{\mathrm{cd}}$ & $35.68 \pm 0.10^{\mathrm{d}}$ & $223.02 \pm 0.64^{\mathrm{d}}$ \\
$\mathrm{SiF} 3+\mathrm{Cd} 100$ & $70.00 \pm 0.58^{\mathrm{f}}$ & $30.42 \pm 0.46^{\mathrm{g}}$ & $190.14 \pm 2.87^{\mathrm{g}}$ \\
$\mathrm{Cd} 200 \mu \mathrm{M}$ & $16.33 \pm 1.76^{\mathrm{i}}$ & $15.32 \pm 0.30^{\mathrm{i}}$ & $95.72 \pm 1.90^{\mathrm{i}}$ \\
$\mathrm{SiR} 3+\mathrm{Cd} 200$ & $80.33 \pm 0.33^{\mathrm{e}}$ & $32.77 \pm 0.18^{\mathrm{ef}}$ & $204.81 \pm 1.16^{\mathrm{ef}}$ \\
$\mathrm{SiF} 3+\mathrm{Cd} 200$ & $51.67 \pm 1.76^{\mathrm{g}}$ & $28.67 \pm 0.25^{\mathrm{g}}$ & $179.21 \pm 1.59^{\mathrm{g}}$ \\
\hline
\end{tabular}

Values show the means of three replications \pm SD. Means followed by same small letters are not significantly different at $\mathrm{P} \leq 0.05$ by using Duncan's multiple range test (DMR)

\section{Discussion}

Plants exposed to several biotic and abiotic stressors in different agriculture systems. Abiotic stressors like heavy metals stress, restrict plant biomass, and limit its yield. In present findings, $\mathrm{Cd}$ existence in nutrient solution at the concentration of $50 \mu \mathrm{M}$, $100 \mu \mathrm{M}$, and $200 \mu \mathrm{M}$ severely decreased wheat plant growth (Fig. 1), silicon (Si) contents (Table 2), chlorophyll contents (Table 2), potassium $\left(\mathrm{K}^{+}\right)$and nitrogen $(\mathrm{N})$ contents (Table 5), while it significantly increased $\mathrm{Cd}$ content (Table 3), Cd translocation and bioaccumulation factors (Table 4), lipid peroxidation measured as malondialdehyde (MDA) content (Fig. 3), enzymatic and non-enzymatic antioxidative contents (Fig. 3). However, Si application either as root or foliar method at a level of $3 \mathrm{mM}$ encountered the negativity of cadmium toxicity in wheat plants by further elevating of enzymatic and non-enzymatic antioxidative contents, reducing Cd, MDA, and $\mathrm{H}_{2} \mathrm{O}_{2}$ contents, resulting in high plant growth. These findings are consistent with Farooq et al. (2013), Howladar et al. (2018), Silva et al. (2017), Alzahrani et al. (2018), Wang et al. (2016), and Rady et al. (2015). The dominant and diverse thing in the current findings that two separate methods of Si supplementation (e.g., foliar spray, root treatment) were tested and the optimum results were attained with Si root application.

Results of the present study demonstrated that $\mathrm{Cd}$ stress interrupted several biological, chemical, and metabolic processes in various plant species (Kim et al., 2014; Shi et al., 2010; Zhang et al., 2014; Zhao et al., 2017). Foyer and Noctor (2005) has been identified $\mathrm{Cd}$ as a disruptor of antioxidant defense system by overproducing oxidative burst and reactive oxygen species (ROS), which enhances lipid peroxidation by MDA contents (Howladar et al., 2018). Cd accumulation gradually increased in plant various parts with preference of root, with the rise of Cd levels in growth medium. Our data showed that higher $\mathrm{Cd}$ accumulation in root than shoot of wheat plants. Plants take up lower amount of metal solution in upper ground part in any event with highest tolerance (Yang et al., 2004). In this study, Cd stress generated high levels of ROS, 
which indicated by severing reduction of photosynthetic gas exchange parameters in leaf, and significant elevations in MDA and $\mathrm{H}_{2} \mathrm{O}_{2}$ contents. Therefore, to meet these adverse conditions, plants are grown under $\mathrm{Cd}$-induced oxidative damage to develop complex antioxidant systems (Dixit et al., 2001; Farooq et al., 2013; Howladar et al., 2018).

Silicon as a high-quality non-corrosive fertilizer enhanced plant existence against $\mathrm{Cd}$ toxicity by significantly interrupted uptake and/or accumulation of $\mathrm{Cd}$ in Cd-toxic plants (Farooq et al., 2013; Song et al., 2009; Wang et al., 2016; Zhao et al., 2017). The constructive effects of $\mathrm{Si}$ on plant physio-biochemical traits under various environmental stresses have been well documented (Hashemi et al., 2010). Previous researchers with different findings (Ali et al., 2013; Kabir et al., 2016b; Shi et al., 2005; Song et al., 2009; Zhao et al., 2017) have suggested optimum methods by which $\mathrm{Si}$ can enhance plant tolerance against abiotic stresses including $\mathrm{Cd}$ that considered the most critical toxic elements, causing limited crop yield in both arid and semiarid regions. The researchers have been conducting various studies to establish $\mathrm{Si}$ beneficial effects on the development and yield of wheat cultivars under Cd toxicity. In our present study, Si found effective fertilizer in demolishing Cd toxicity in the wheat plant. The growth traits were significantly elevated in stressed-plants to normal with Si supplementation. Si causes nutritional balance and increases dry matter production of plants while applied in suitable dose (Silva et al., 2017). According to the results of the present study, nutrient medium receiving $\mathrm{Si}$ or plants received $\mathrm{Si}$ as foliar spray increased growth of stress wheat plants. This upgrading in wheat growth may be recognized to that $\mathrm{Si}$ improved photosynthetic rate that is correlated to activity of ribulose biphosphate carboxylase, leaf ultrastructure, and leaf chlorophyll contents (Hamayun et al., 2010).

Oxidative damage generally caused in plants due to ROS, e.g., superoxide radical, $\mathrm{H}_{2} \mathrm{O}_{2}$, and hydroxyl radical $\left(\mathrm{OH}^{-1}\right)$ (Shahid et al., 2014; Tamás et al., 2017). Along with the overproduction of ROS, membrane permeability with lipid peroxidation is also the main mechanism in higher plants due to Cd exposure (Farooq et al., 2013). MDA, as a derivative of lipid peroxidation, destabilized cell membrane integrity, and higher the risk of its permeability in various crops (Moussa, 2006; Soylemezoglu et al., 2009). In our findings, $\mathrm{Si}$ supplementation significantly lowers the malondialdehyde (MDA) contents in Cd-stressed wheat plants, resulting in sustain cell membranes integrity and reduce their permeability in Cd stress. Plants have various enzymatic (CAT, SOD, and POD) and non-enzymatic (proline) antioxidant defense systems to control different productions of ROS. Among these protective defense systems, the fusion of osmolytes/osmoprotectants is one of the integral protective mechanisms of plants grown in stress conditions (Rios et al., 2017). Proline as osmoprotectants protects plant cells by neutralizing osmotic strength of external environment and the cytosol and vacuole osmotic strengths under salt stress (Gadallah, 1999).

Furthermore, proline, as an impotent osmolyte accumulated in response to osmotic stress, contributes to osmotic adjustments in plant cells (Gadallah, 1999). Proline contents scavenge free radicals of oxidative stress molecules, stabilizes protein and sub-cellular structures under Cd stress (Sharma and Dubey, 2005). As an optimum Si application method, Si root-application improved proline accumulation in wheat plants to increase plant chances to withstand under oxidative stress induced by $\mathrm{Cd}$ (Fig. 3). 
Enzymatic antioxidants included catalase (CAT), superoxide dismutase (SOD), peroxidase (POD), etc. is another defense system in various stresses including Cd (Şen, 2012). In the current study, enzymatic antioxidant activities were higher with $\mathrm{Cd}$ induced oxidative stress and were further improved with $\mathrm{Si}$ supplementation with the preference of $\mathrm{Si}$ root-application. Cd-induced oxidative stress resulted superoxide radicals that were transformed into $\mathrm{H}_{2} \mathrm{O}_{2}$ by SOD. $\mathrm{H}_{2} \mathrm{O}_{2}$ is a powerful oxidant that is accumulated in plant tissues from SOD canalization reaction and is prohibited by the cycle of ascorbate-glutathione. Except $\mathrm{H}_{2} \mathrm{O}_{2}$, another lethal oxide is the $\mathrm{OH}^{-1}$, which can combine with all macro-molecules. By assimilating their actions, both CAT and SOD can stop $\mathrm{OH}^{-1}$ formation in plant tissues (Kusvuran et al., 2016). It has established in previous findings that Si application elevated CAT and SOD (Howladar et al., 2018). Kabir et al. (2016b) found that addition of Si under stress considerably improved CAT and SOD activities in alfalfa plants. Peroxidases (PODs) due to their role in consuming and scavenging $\mathrm{H}_{2} \mathrm{O}_{2}$ can modify ROS levels in plants. Compared to SOD and CAT, PODs have high attraction to $\mathrm{H}_{2} \mathrm{O}_{2}$, though PODs can also produce $\mathrm{H}_{2} \mathrm{O}_{2}$ by the oxidation of NAD(P)H (Ranieri et al., 2005). Several scientists have reported in their findings that $\mathrm{Si}$ application elevated POD activity in plants grown under oxidative stress. In general, Si treatment reduced ROS generation and led to raising enzymatic and non-enzymatic anti-oxidants used to scavenge ROS (Rios et al., 2017). Therefore, Si uses ROS scavenging metabolic pathways more effectively, which makes it able to alleviate Cd-induced oxidative stress at cellular level, which may recover the integrity of cell membranes.

$\mathrm{Cd}$ accumulation in shoots and roots of wheat plants followed the same trend as shoots, and roots levels reduced with increasing Si dose as a foliar application. The same results found by previous reports (Treder and Cieslinski, 2005), but our results were conflicted with the finding of several studies that examined decreased shoots $\mathrm{Cd}$ concentration with increasing $\mathrm{Si}$ levels (Rizwan et al., 2012). Interestingly, contradictory results were obtained in case of $\mathrm{Si}$ root application as $\mathrm{Cd}$ concentration did not follow the same trend as $\mathrm{Cd}$ reduced in all three parts of plants than that of $\mathrm{Cd}$ alone treatments. But our consequences were conflicted with the finding of several studies which examined decreased $\mathrm{Cd}$ shoots concentration with increasing $\mathrm{Si}$ levels (Rizwan et al., 2012). Interestingly, contradictory results were obtained in case of Si root application as $\mathrm{Cd}$ concentration did not follow the same trend, i.e., $\mathrm{Cd}$ shoot concentrations declined while root concentrations elevated with increasing $\mathrm{Si}$ dose. Similar results were also found in durum wheat developed in a soil with aged impurity (Rizwan et al., 2012), rice is grown hydroponically (Shi et al., 2005; Zhang et al., 2008), in peanut and cucumber (Shi et al., 2010) and Brassica Chinensis (Song et al., 2009), but our results in case of SiR3 disagreed with authors who found Cd increased in both root and shoot with the increase in Si doses (Vaculík et al., 2009), or a decrease in Cd concentration in both roots and leaves with increase in Si levels (Nwugo and Huerta, 2008). In Si root application, increased Cd concentration in roots could be due to the deposition of $\mathrm{Cd}$ in roots and formed metal complexes with silicates as reported by numerous studies. i.e., Zhang et al. (2008) established that Cd usually deposited in the section of roots endodermis and epidermis in rice plants, while, Shi et al. (2010) found that $\mathrm{Si}$ often stored in the cell walls of the endodermis and formed metal complexes with silicates. However, in $\mathrm{SiF} 3$ application $\mathrm{Cd}$ concentration in both roots and shoots was decreased with increasing Si levels, it could be due to $\mathrm{Si}$ inhibitory behavior, $\mathrm{Si}$ deposited in leaves cells and translocated from leaves to shoot and then roots and 
inhibited Cd translocation through xylem and phloem (Treder and Cieslinski, 2005). In both methods of $\mathrm{Si}$, application plant withstand against $\mathrm{Cd}$ toxicity may be attributed due to the improvement of plant tolerance and/or due to uptake and transport of $\mathrm{Cd}$ which was also reported by Wang et al. (2016). In our study Cd concentration was high in $\mathrm{Cd}$ alone treatments as compared to $\mathrm{Cd}+\mathrm{Si}$ (Table 2) that were conflicted with the findings of various authors who found that the $\mathrm{Cd}$ concentration in both roots and shoots was higher in $\mathrm{Cd}+\mathrm{Si}$ treated plants than alone Cd-treated plants (Prabagar et al., 2011; Ye et al., 2012). Our results showed $\mathrm{TF}<1$ suggesting that $\mathrm{Cd}$ could ineffectively be translocated from root to shoots in case of both SiF3 and SiR3, but more significant effects observed in the case of SiR3 (Table 5) which is in line of previous findings (Howladar et al., 2018). In our study Si concentration under Cd stress was significantly increased with Si supplementation (Silva et al., 2017), which clarified that in Si both application methods, Si absorbed by roots should have translocation into shoots, where it deposits in the leaf apoplast as a polymer, forming a crucial barrier to protect plants from various environmental stresses counting $\mathrm{Cd}$ stress. Furthermore, Si concentration in plant showed a negative correlation with TF, BAF, and BCF of Cd (Fig. 4), which suggests that with the increase of $\mathrm{Si}$ concentration in plants, $\mathrm{Cd}$ translocation and bioaccumulation will decrease simultaneously. Our results showed that BAF of $\mathrm{Cd}$ decreased with the rise of $\mathrm{Cd}$ concentration in nutrient solution (Table 5) which was in line of previous findings (Zhao et al., 2003) but was contrary with some scientists who found increase in BAF with increase of heavy metal accumulation in soil (Rezvani and Zaefarian, 2011).

Micro and macronutrients play an optimum role in the maintenance of biochemical processes, plant growth, and high plant yield if they are up taken in a controlled way, transported to a long distance, and then correctly utilize. Si application against chromium $(\mathrm{Cr})$ and $\mathrm{Cd}$ stress improved the utilization of macro $\left(\mathrm{Ca}^{++}, \mathrm{Mg}^{++}\right.$, and $\left.\mathrm{K}^{+}\right)$ and microelements (Fe and $\mathrm{Zn}$ ) (Tripathi et al., 2012). Our results showed a strong positive correlation between $\mathrm{Si}$ and $\mathrm{K}^{+}$concentration, which means with the increase of Si concentration in solution $\mathrm{K}^{+}$would also be increased simultaneously (Fig. 4). Previous studies (Jayakannan et al., 2013) showed that Si application increased $\mathrm{K}^{+}$ concentration plants under abiotic stresses. According to our hypothesis, Si might improve $\mathrm{K}^{+}$concentration in stressed-plants by mitigating nutrient imbalance created by Cd-stress. Our study showed that $\mathrm{Si}$ and $\mathrm{K}^{+}$have positive effects on the production of ROS in plants under stress conditions (Table 4).

\section{Conclusion}

In conclusion, the addition of $\mathrm{Si}$ has been proved high-quality non-corrosive fertilizer under the hostile conditions of Cd-stressed wheat seedlings as a study herein. Our data demonstrated that $\mathrm{Si}$ supplementation, with the preference of root application, significantly improved growth traits by successfully encountered toxic belongings of $\mathrm{Cd}$ stress. Si root-application enhanced all recorded parameters such as photosynthetic pigments, enzymatic (CAT, SOD, POD), and non-enzymatic (proline) antioxidants and demolished MDA, $\mathrm{H}_{2} \mathrm{O}_{2}$, and $\mathrm{Cd}$ contents. Si showed the antagonistic effect with $\mathrm{Cd}$ concentration in plants and showed synergetic effect with essential nutrients like $\mathrm{K}$ and N. After analyzing the recorded data, we can be strongly emphasized that $\mathrm{Si}$ supplementation with the preference of root-application must be used as an optimum approach to reduce $\mathrm{Cd}$ toxicity in wheat plants. 
Acknowledgments. The authors would like to extend their sincere gratitude to the Agriculture Water and Soil Environment Field Science Research Station, China, for the permission to carry out the research. The Central Public-Interest Scientific Institution supported this research Basal Research Fund (Farmland Irrigation Research Institute, CAAS, FIRI2013-17), by the Agricultural Science and Technology Innovation Program (Grant no. CAAS-ASTIP-FIRE-03), Chinese Academy of Agricultural Sciences and by the National Natural Science Foundation of China (Grant no. 51679241, 51709265).

\section{REFERENCES}

[1] Ali, B., Qian, P., Jin, R., Ali, S., Khan, M., Aziz, R., Tian, T., Zhou, W. (2014): Physiological and ultra-structural changes in Brassica napus seedlings induced by cadmium stress. - Biologia Plantarum 58: 131-138.

[2] Ali, S., Zeng, F., Cai, S., Qiu, B., Zhang, G. (2011): The interaction of salinity and chromium in the influence of barley growth and oxidative stress. - Plant Soil Environ 57: 153-159.

[3] Ali, S., Farooq, M., Jahangir, M., Abbas, F., Bharwana, S., Zhang, G. (2013): Effect of chromium and nitrogen form on photosynthesis and anti-oxidative system in barley. Biologia Plantarum 57: 758-763.

[4] Alzahrani, Y., Kuşvuran, A., Alharby, H. F., Kuşvuran, S., Rady, M. M. (2018): The defensive role of silicon in wheat against stress conditions induced by drought, salinity or cadmium. - Ecotoxicol Environ Saf 154: 187-196.

[5] Azevedo, R. A., Gratão, P. L., Monteiro, C. C., Carvalho, R. F. (2012): What is new in the research on cadmium-induced stress in plants? - Food and Energy Security 1: 133140.

[6] Balakhnina, T., Bulak, P., Nosalewicz, M., Pietruszewski, S., Włodarczyk, T. (2015): The influence of wheat Triticum aestivum L. seed pre-sowing treatment with magnetic fields on germination, seedling growth, and antioxidant potential under optimal soil watering and flooding. - Acta Physiologiae Plantarum 37: 59.

[7] Dixit, V., Pandey, V., Shyam, R. (2001): Differential antioxidative responses to cadmium in roots and leaves of pea (Pisum sativum L. cv. Azad). - Journal of Experimental Botany 52: 1101-1109.

[8] Dong, Q., Fang, J., Huang, F., Cai, K. (2019): Silicon amendment reduces soil Cd availability and $\mathrm{Cd}$ uptake of two Pennisetum species. - International Journal of Environmental Research and Public Health 16: 1624.

[9] Farooq, M. A., Ali, S., Hameed, A., Ishaque, W., Mahmood, K., Iqbal, Z. (2013): Alleviation of cadmium toxicity by silicon is related to elevated photosynthesis, antioxidant enzymes; suppressed cadmium uptake and oxidative stress in cotton. Ecotoxicology and Environmental Safety 96: 242-249.

[10] Fırat, M., Bakırdere, S., Findıkoğlu, M. S., Kafa, E. B., Yazıcı, E., Yolcu, M., Büyükpınar, Ç., Chormey, D. S., Sel, S., Turak, F. (2017): Determination of trace amount of cadmium using dispersive liquid-liquid microextraction-slotted quartz tubeflame atomic absorption spectrometry. - Spectrochimica Acta Part B: Atomic Spectroscopy 129: 37-41.

[11] Flister, L., Galushko, V. (2016): The impact of wheat market liberalization on the seed industry's innovative capacity: an assessment of Brazil's experience. - Agricultural and Food Economics 4: 11.

[12] Foyer, C. H., Noctor, G. (2005): Redox homeostasis and antioxidant signaling: a metabolic interface between stress perception and physiological responses. - The Plant Cell 17: 1866-1875.

[13] Fu, S., Wei, C. Y. (2013): Multivariate and spatial analysis of heavy metal sources and variations in a large old antimony mine, China. - Journal of Soils and Sediments 13: 106-116. 
[14] Gadallah, M. (1999): Effects of proline and glycinebetaine on Vicia faba responses to salt stress. - Biologia Plantarum 42: 249-257.

[15] Gratão, P. L., Polle, A., Lea, P. J., Azevedo, R. A. (2005): Making the life of heavy metal-stressed plants a little easier. - Functional Plant Biology 32: 481-494.

[16] Hamayun, M., Sohn, E.-Y., Khan, S. A., Shinwari, Z. K., Khan, A. L., Lee, I.-J. (2010): Silicon alleviates the adverse effects of salinity and drought stress on growth and endogenous plant growth hormones of soybean (Glycine max L.). - Pakistan Journal of Botany 42: 1713-1722.

[17] Hashemi, A., Abdolzadeh, A., Sadeghipour, H. R. (2010): Beneficial effects of silicon nutrition in alleviating salinity stress in hydroponically grown canola, Brassica napus L., plants. - Soil Science \& Plant Nutrition 56: 244-253.

[18] Howladar, S. M., Al-Robai, S. A., Al-Zahrani, F. S., Howladar, M. M., Aldhebiani, A. Y. (2018): Silicon and its application method effects on modulation of cadmium stress responses in Triticum aestivum (L.) through improving the antioxidative defense system and polyamine gene expression. - Ecotoxicol Environ Saf 159: 143-152.

[19] Jayakannan, M., Bose, J., Babourina, O., Rengel, Z., Shabala, S. (2013): Salicylic acid improves salinity tolerance in Arabidopsis by restoring membrane potential and preventing salt-induced $\mathrm{K}+$ loss via a GORK channel. - Journal of Experimental Botany 64: 2255-2268.

[20] Kabir, A. H., Hossain, M. M., Khatun, M. A., Mandal, A., Haider, S. A. (2016a): Role of silicon counteracting cadmium toxicity in alfalfa (Medicago sativa L.). - Frontiers in Plant Science 7: 1117.

[21] Kabir, A. H., Hossain, M. M., Khatun, M. A., Mandal, A., Haider, S. A. (2016b): Role of silicon counteracting cadmium toxicity in alfalfa (Medicago sativa L.). - Front Plant Sci 7: 1117.

[22] Keeping, M. G. (2017): Uptake of silicon by sugarcane from applied sources may not reflect plant-available soil silicon and total silicon content of sources. - Frontiers in Plant Science 8: 760.

[23] Kim, Y. H., Khan, A. L., Waqas, M., Shim, J. K., Kim, D. H., Lee, K. Y., Lee, I. J. (2014): Silicon application to rice root zone influenced the phytohormonal and antioxidant responses under salinity stress. - Journal of Plant Growth Regulation 33: 137-149.

[24] Kim, Y. H., Khan, A. L., Waqas, M., Lee, I.-J. (2017): Silicon regulates antioxidant activities of crop plants under abiotic-induced oxidative stress: a review. - Frontiers in Plant Science 8: 510.

[25] Kusvuran, S., Kiran, S., Ellialtioglu, S. S. (2016): Antioxidant Enzyme Activities and Abiotic Stress Tolerance Relationship in Vegetable Crops. - In: Shanker A., Shanker, C. (eds.) Abiotic and Biotic Stress in Plants. InTech Open, London, pp. 481-503.

[26] Li, W., Xu, B., Song, Q., Liu, X., Xu, J., Brookes, P. C. (2014): The identification of 'hotspots' of heavy metal pollution in soil-rice systems at a regional scale in eastern China. - Science of the Total Environment 472: 407-420.

[27] Ma, J., Miyake, Y., Takahashi, E. (2001a): Silicon as a Beneficial Element for Crop Plants. - In: Datnoff, L. E. et al. (eds.) Silicon in Agriculture. Series: Studies in Plant Science, Vol. 8. Elsevier, Amsterdam, pp. 17-39.

[28] Ma, L. Q., Komar, K. M., Tu, C., Zhang, W., Cai, Y., Kennelley, E. D. (2001b): A fern that hyperaccumulates arsenic. - Nature 409: 579.

[29] Metzner, H., Rau, H., Senger, H. (1965): Untersuchungen zur Synchronisierbarkeit einzelner Pigmentmangel-Mutanten von Chlorella. (Studies on synchronization of some pigment-deficient Chlorella mutants.) - Planta 65: 186-194.

[30] Moussa, H. R. (2006): Influence of exogenous application of silicon on physiological response of salt-stressed maize (Zea mays L.). - International Journal of Agriculture and Biology 8: 293-297. 
[31] Nwugo, C. C., Huerta, A. J. (2008): Effects of silicon nutrition on cadmium uptake, growth and photosynthesis of rice plants exposed to low-level cadmium. - Plant and Soil 311: 73-86.

[32] Prabagar, S., Hodson, M. J., Evans, D. E. (2011): Silicon amelioration of aluminium toxicity and cell death in suspension cultures of Norway spruce (Picea abies (L.) Karst.). - Environmental and Experimental Botany 70: 266-276.

[33] Rady, M. M., Hemida, K. A. (2015): Modulation of cadmium toxicity and enhancing cadmium-tolerance in wheat seedlings by exogenous application of polyamines. Ecotoxicology and Environmental Safety 119: 178-185.

[34] Ranieri, A., Castagna, A., Scebba, F., Careri, M., Zagnoni, I., Predieri, G., Pagliari, M., di Toppi, L. S. (2005): Oxidative stress and phytochelatin characterisation in bread wheat exposed to cadmium excess. - Plant Physiol Biochem 43: 45-54.

[35] Rascio, N., Navari-Izzo, F. (2011): Heavy metal hyperaccumulating plants: how and why do they do it? And what makes them so interesting? - Plant Science 180: 169-181.

[36] Rezvani, M., Zaefarian, F. (2011): Bioaccumulation and translocation factors of cadmium and lead in 'Aeluropus littoralis'. - Australian Journal of Agricultural Engineering 2: 114.

[37] Rios, J. J., Martínez-Ballesta, M. C., Ruiz, J. M., Blasco, B., Carvajal, M. (2017): Silicon-mediated improvement in plant salinity tolerance: the role of aquaporins. Frontiers in Plant Science 8: 948.

[38] Rizwan, M., Meunier, J.-D., Miche, H., Keller, C. (2012): Effect of silicon on reducing cadmium toxicity in durum wheat (Triticum turgidum L. cv. Claudio W.) grown in a soil with aged contamination. - Journal of Hazardous Materials 209: 326-334.

[39] Şen, A. (2012): Oxidative Stress Studies in Plant Tissue Culture. - In: El-Missiry, M. A. (ed.) Antioxidant Enzyme. InTech Open, London, pp. 59-88.

[40] Sergiev, P. V., Lavrik, I. N., Wlasoff, V. A., Dokudovskaya, S. S., Dontsova, O. A., Bogdanov, A. A., Brimacombe, R. (1997): The path of mRNA through the bacterial ribosome: a site-directed crosslinking study using new photoreactive derivatives of guanosine and uridine. - RNA 3: 464.

[41] Shahid, M., Pourrut, B., Dumat, C., Nadeem, M., Aslam, M., Pinelli, E. (2014): Heavymetal-induced reactive oxygen species: phytotoxicity and physicochemical changes in plants. - Reviews of Environmental Contamination and Toxicology 232: 1-44.

[42] Sharma, P., Dubey, R. S. (2005): Modulation of nitrate reductase activity in rice seedlings under aluminium toxicity and water stress: role of osmolytes as enzyme protectant. - Journal of Plant Physiology 162: 854-864.

[43] Shi, G., Cai, Q., Liu, C., Wu, L. (2010): Silicon alleviates cadmium toxicity in peanut plants in relation to cadmium distribution and stimulation of antioxidative enzymes. Plant Growth Regulation 61: 45-52.

[44] Shi, X., Zhang, C., Wang, H., Zhang, F. (2005): Effect of Si on the distribution of Cd in rice seedlings. - Plant and Soil 272: 53-60.

[45] Shi, Y., Zhang, Y., Yao, H., Wu, J., Sun, H., Gong, H. J. (2014): Silicon improves seed germination and alleviates oxidative stress of bud seedlings in tomato under water deficit stress. - Plant Physiol Biochem 78: 27-36.

[46] Silva, A., Nascimento, C., Gouveia-Neto, A. J. P. (2017): Assessment of cadmium phytotoxicity alleviation by silicon using chlorophyll a fluorescence. - Rev Environ Contam Toxicol 55: 648-654.

[47] Sommer, M., Kaczorek, D., Kuzyakov, Y., Breuer, J. J. (2006): Silicon pools and fluxes in soils and landscapes - a review. - Journal of Plant Nutrition and Soil Science 169: 310-329.

[48] Song, A., Li, Z., Zhang, J., Xue, G., Fan, F., Liang, Y. (2009): Silicon-enhanced resistance to cadmium toxicity in Brassica chinensis L. is attributed to Si-suppressed cadmium uptake and transport and Si-enhanced antioxidant defense capacity. - Journal of Hazardous Materials 172: 74-83. 
[49] Soylemezoglu, G., Demir, K., Inal, A., Gunes, A. (2009): Effect of silicon on antioxidant and stomatal response of two grapevine (Vitis vinifera L.) rootstocks grown in boron toxic, saline and boron toxic-saline soil. - Scientia Horticulturae 123: 240-246.

[50] Takahashi, R., Ishimaru, Y., Shimo, H., Ogo, Y., Senoura, T., Nishizawa, N. K., Nakanishi, H. (2012): The OsHMA2 transporter is involved in root-to-shoot translocation of $\mathrm{Zn}$ and Cd in rice. - Plant, Cell \& Environment 35: 1948-1957.

[51] Tamás, L., Mistrík, I., Zelinová, V. (2017): Heavy metal-induced reactive oxygen species and cell death in barley root tip. - Environmental and Experimental Botany 140: $34-40$.

[52] Treder, W., Cieslinski, G. (2005): Effect of silicon application on cadmium uptake and distribution in strawberry plants grown on contaminated soils. - Journal of Plant Nutrition 28: 917-929.

[53] Tripathi, D. K., Singh, V. P., Kumar, D., Chauhan, D. K. (2012): Rice seedlings under cadmium stress: effect of silicon on growth, cadmium uptake, oxidative stress, antioxidant capacity and root and leaf structures. - Chemistry and Ecology 28: 281-291.

[54] Vaculík, M., Lux, A., Luxová, M., Tanimoto, E., Lichtscheidl, I. (2009): Silicon mitigates cadmium inhibitory effects in young maize plants. - Environmental and Experimental Botany 67: 52-58.

[55] Vieira da Cunha, P. K., Araújo do Nascimento, W. C., da Silva, J. A. (2008): Silicon alleviates the toxicity of cadmium and zinc for maize (Zea mays L.) grown on a contaminated soil. - Journal of Plant Nutrition and Soil Science 171: 849-853.

[56] Wael, M. S., Mostafa, M. R., Taia, A. A. E.-M., Saad, M. H., Magdi, T. A. J. (2015): Alleviation of cadmium toxicity in common bean (Phaseolus vulgaris L.) plants by the exogenous application of salicylic acid. - The Journal of Horticultural Science and Biotechnology 90: 83-91.

[57] Wang, Y., Hu, Y., Duan, Y., Feng, R., Gong, H. (2016): Silicon reduces long-term cadmium toxicities in potted garlic plants. - Acta Physiologiae Plantarum 38: 211.

[58] Wuana, R. A., Okieimen, F. E. (2011): Heavy metals in contaminated soils: a review of sources, chemistry, risks and best available strategies for remediation. - International Scholarly Research Notices Ecology. https://doi.org/10.5402/2011/402647.

[59] Yang, X., Long, X., Ye, H., He, Z., Calvert, D., Stoffella, P. (2004): Cadmium tolerance and hyperaccumulation in a new Zn-hyperaccumulating plant species (Sedum alfredii Hance). - Plant and Soil 259: 181-189.

[60] Ye, J., Yan, C., Liu, J., Lu, H., Liu, T., Song, Z. (2012): Effects of silicon on the distribution of cadmium compartmentation in root tips of Kandelia obovata (S., L.) Yong. - Environmental Pollution 162: 369-373.

[61] Yu, H.-Y., Ding, X., Li, F., Wang, X., Zhang, S., Yi, J., Liu, C., Xu, X., Wang, Q. (2016): The availabilities of arsenic and cadmium in rice paddy fields from a mining area: the role of soil extractable and plant silicon. - Environmental Pollution 215: 258265.

[62] Zabin, S. A., Howladar, S. M. (2015): Accumulation of $\mathrm{Cu}, \mathrm{Ni}$ and $\mathrm{Pb}$ in selected native plants growing naturally in sediments of water reservoir dams, Albaha region, KSA. - Nature and Science of Sleep 13: 11-17.

[63] Zhang, C., Wang, L., Nie, Q., Zhang, W., Zhang, F. (2008): Long-term effects of exogenous silicon on cadmium translocation and toxicity in rice (Oryza sativa L.). Environmental and Experimental Botany 62: 300-307.

[64] Zhang, Q., Yan, C., Liu, J., Lu, H., Duan, H., Du, J., Wang, W. (2014): Silicon alleviation of cadmium toxicity in mangrove (Avicennia marina) in relation to cadmium compartmentation. - Journal of Plant Growth Regulation 33: 233-242.

[65] Zhang, W., Cai, Y., Tu, C., Ma, L. Q. (2002): Arsenic speciation and distribution in an arsenic hyperaccumulating plant. - Science of the Total Environment 300: 167-177. 
[66] Zhao, F., Lombi, E., McGrath, S. (2003): Assessing the potential for zinc and cadmium phytoremediation with the hyperaccumulator Thlaspi caerulescens. - Plant and Soil 249: 37-43.

[67] Zhao, M., Liu, Y., Li, H., Cai, Y., Wang, M. K., Chen, Y., Xie, T., Wang, G. (2017): Effects and mechanisms of meta-sodium silicate amendments on lead uptake and accumulation by rice. - Environmental Science and Pollution Research 24: 2170021709

\section{APPENDIX}

\section{Recipe of Hoagland's solution}

The Hoagland's solution had composition (mg L-1): (NH4)2SO4 48.2, MgSO4 65.9, K2SO4 15.9, KNO3 18.5, Ca (NO3)2 59.9, KH2PO4 24.8, Fe citrate 6.8, MnCl2.4H2O 0.9, ZnSO4.7H2O 0.11, CuSO4.5H2O 0.04, H3BO3 2.9, H2MoO4 0.01.

\section{Recipe of Si treatment}

Silicon $(\mathrm{Si})$ as a silica nanoparticle prepared from sodium silicate. A measured amount of sodium silicate put into the double amount of boiling deionized distilled water in a petri dish for 10 min. For increasing its solubility, we added a small amount of $\mathrm{KOH}$ and further heated for $10 \mathrm{~min}$. Continue stirring with a long-handled spoon and at the end added 2 to 3 drops of $\mathrm{H}_{2} \mathrm{O}_{2}$. The solution removed from heat stove and allowed it to cool at room temperature. Cooled solution transferred into a plastic bottle and sealed it up. From the prepared stock solution, we made subsolution of $3 \mathrm{mM} / \mathrm{L}$ and applied as $\mathrm{SiF} 3$ and $\mathrm{SiR} 3$. Both treatments $\mathrm{Si}$ and $\mathrm{Cd}$ were applied after 65 days of transplantation. The twelve treatments were arranged factorially in a randomized complete block design with three replications per treatments. A total number of pots were 36 , and each pot contained 15 plants.

\section{Recipe to determine nutrient elements in plant tissues}

$\mathrm{Cd}$ and $\mathrm{Si}$ were measured in plant root and shoot dry masses by atomic absorption spectrometry method with some necessary modifications (Firat et al., 2017). After 35 days of treatments, wheat plants were harvested and washed thoroughly with tap water, distilled water, and then with double distilled water. Plant samples were separated into roots and shoots and dried at $70{ }^{\circ} \mathrm{C}$ in the oven for $48 \mathrm{~h}$, and ground into powder. Weighed $0.2 \mathrm{~g}$ of dried plant sample was placed into a microwave digestion tube. Added $10 \mathrm{ml}$ of nitric acid and covered every sample with a lid. Later, it was put into the microwave digestion instrument and started to dissolve after selection of an appropriate program. After completion of digestion, tubes were removed and put the digestion solution into the PTFE digestion cup with a small number of repeated flushing. Digestion cups were placed on a hot plate at $220{ }^{\circ} \mathrm{C}$ temperature until the removal of 2-3 ml liquid. In the end, the digestion fluid was transferred into the $50 \mathrm{ml}$ volumetric flask and made its volume up to $50 \mathrm{ml}$ with double distilled water. Digestion solution used to measure $\mathrm{Cd}$ and $\mathrm{Si}$ concentrations in root and shoots by using an atomic absorption spectrophotometer (AAS) model AA-6300 SHIMADZU. The total contents of $\mathrm{Cd}$ and Si per plant were calculated from $\mathrm{Cd}$ and $\mathrm{Si}$ concentration $\left(\mu \mathrm{g} \mathrm{g}^{-1}\right)$ and meant 
the dry weight of below- and above- ground parts. Total nitrogen was measured in plants by the method of (Brookes et al., 1985) with some modifications. Weighted $0.3 \mathrm{~g}$ of plant dry sample in digestion tubes with $4 \mathrm{ml}$ of sulphuric acid was put on the curved stem small funnel into the digestion furnace and initiated to dissolve. The temperature was set to $220^{\circ} \mathrm{C}$ for $2 \mathrm{~h}$ and boiled till brown, yellow endpoint. First, samples were heated at $380{ }^{\circ} \mathrm{C}$ and removed these digestion tubes from digestion furnace. Added 20 drops of hydrogen peroxide $\left(\mathrm{H}_{2} \mathrm{O}_{2}\right)$ and samples were placed on hot plate and continue to heat again. This cycle was repeated 2-5 times to clear the digestion solution. At every cycle, the amount of $\mathrm{H}_{2} \mathrm{O}_{2}$ was decreased. The amount of $\mathrm{H}_{2} \mathrm{O}_{2}$ added to the blank was consistent with the maximum number of samples. After that, a few amounts of multiple flushing methods were transferred to the $100 \mathrm{ml}$ volumetric flask. In the end, total nitrogen was determined in a solution using flow analyzer-3 of brand BRAN + LUEBBE, and potassium was determined in a solution using flame photometer FP6410.

\section{Determination of biochemical parameters}

For MDA measurement, $0.25 \mathrm{~g}$ leaf sample was homogenized in $5 \mathrm{ml} 0.1 \%$ TCA. The homogenate was centrifuged at $10,000 \times \mathrm{g}$ for $10 \mathrm{~min}$. to $1 \mathrm{ml}$ aliquot of the supernatant, $4 \mathrm{ml}$ of $20 \%$ TCA containing $0.5 \%$ TBA was added. The mixture was heated at $95{ }^{\circ} \mathrm{C}$ for $30 \mathrm{~min}$ and then quickly cooled in the ice bath. After centrifugation at $10,000 \times \mathrm{g}$ for $10 \mathrm{~min}$, the absorbance of the supernatant at $532 \mathrm{~nm}$ was read and the value of the nonspecific absorption at $600 \mathrm{~nm}$ was subtract. The MDA content was calculated by using an extinction coefficient of $155 \mathrm{mM}^{-1} \mathrm{~cm}^{-1}$. For the measurement of $\mathrm{H} 2 \mathrm{O} 2$, we weighted $0.5 \mathrm{~g}$ leaf tissues were homogenized in an ice bath with $5 \mathrm{ml} 0.1 \%$ $(\mathrm{W} / \mathrm{V})$ trichloroacetic acid $(\mathrm{TCA})$. The homogenate was centrifuged at $12000 \times \mathrm{g}$ for $15 \mathrm{~min}$ and $0.5 \mathrm{ml}$ of the supernatant was added to $0.05 \mathrm{ml} 10 \mathrm{mM}$ potassium phosphate buffer $(\mathrm{pH} \mathrm{7.0)}$ and $1 \mathrm{ml} 1 \mathrm{M} \mathrm{KI}$. The absorbency of supernatant was assessed at $390 \mathrm{~nm}$. 